\title{
Preliminary faunistic assessment of weevils living in areas of the Nature 2000 Site „Eastern Cluj Hills” (Romania) impacted by human (Coleoptera: Curculionoidea)
}

\author{
Lucian Alexandru TeOdor, Alexandru CrişAn, Mihaela OnIŞA \& Dragomir-Cosmin DAVID
}

\begin{abstract}
Summary: From the areas impacted by human pressure in the Nature 2000 Site „Eastern Cluj Hills” (Romania), 102 weevil species (Coleoptera: Curculionoidea) are recorded in a relatively short period and irregularly collecting (June and August 2014, May-June 2015 and 2016). The most diverse and rich (42 species) weevil fauna occur grasslands of Bădeşti. Mecinus plantaginis is recorded for the first time from Romania, and Mogulones larvatus, Argoptochus quadrisignatus, Lixus cylindrus and L. angustus, are rare in the country. The most common are: Protapion apricans, Mecinus pyraster, Tychius quinquepunctatus, Phyllobius pyri, Ph. betulinus and Anthonomus rubi, and the most numerous populations form: Sciaphobus caesius, Larinus obtusus, Eusomus ovulum, Foucartia ptochoides and species of genera: Sitona, Phyllobius and Polydrusus. These preliminary results suggests much higher diversity and richness of weevils in the Nature 2000 Site „Eastern Cluj Hills”, what should be confirmed by further study.
\end{abstract}

Key words: weevils, faunistic, rare species, Eastern Cluj Hills, Romania

\section{Introduction}

Weevils in a broad sense (Superfamily Curculionoidea) is one of the largest group of phytophagous beetles in the world (LAWRENCE and Newton 1995, Alonso-Zarazaga and Lyal 1999, RHEINHEIMER and HASSLER 2010), well representing in the Palaearctic Region (Alonso - ZarazaGa et al. 2017). Study of the richness and diversity of organisms currently living in protected areas of the Carpathians, especially from Nature 2000 Sites, including weevils, is one of the priority tasks of modern faunistical research in Romania, as well as in other countries of the Carpathian Basin (CRIŞAN et al. 1999; GuŞă 2005; Guşă and Blaga 2006; KNUTELSKI 2005, KNUTELSKI and Surowiak 2011; Kocs 1996; Mazur 2002, 2011; PešÍć 2002, 2014; Pešić et al. 2018; PodlussáNY 1981, 1986, 1992; Podlussány and Kocs 1995, 1997; Procheș 1998; Stejskal 2004; TeOdOR 1993a, 1993b; TeOdor and Crişan 1996, 2002, 2010; TeOdor and DĂNILĂ 1994, 1997, 2011; TEODOR and MANOLE 1996; Teodor and Milin 2013; Teodor et al. 1999, 2000, $2001,2010)$. This study is a continuation of that process and are a contribution to the knowledge the overall biodiversity of protected natural areas in Romania, as well as in all area of the Carpathians. Currently, there are no published data on the weevils from the Nature 2000 Site "Eastern Cluj Hills".

Assessment diversity and richness of weevils living in the areas impacted by different kind of human pressure, especially meadows, in the Nature 2000 Site
„Eastern Cluj Hills” (Romania, Transylvania), was the aim of our study. We also have been wanted to find out how meadow weevils respond to various forms of human impact in the study area. At the beginning, we adopted the hypothesis that the diversity and richness of weevil species on meadows traditionally and mechanically mowed with light mowers (Brielmaier mowers) and on extensively grazed and abandoned, should be higher than on meadows mowed with heavy equipment and intensively grazed.

\section{Study area}

The Cluj Hills are located in the South-Eastern part of the Someșan Plateau. Within this geographical unit, the site of community importance ROSCI0295 Eastern Cluj Hills (Dealurile Clujului de Est) and the protected natural area of national importance Fânațele Clujului are delimited, sites in which the studies concerning weevils were performed (PoP 2012, RÁKosy et al. 2018). The study of weevils was conducted in different biotopes: mixed deciduous forests and meadows (hay meadows and pastures) at 12 localities within or in the vicinity of the site with 31 different biotopes (Fig. 1): extensively grazed meadows (PE) and intensively grazed meadows (PI), along with traditionally mowed meadows (MT), mechanically mowed meadows with Brielmaier mowers (MB), mechanically mowed meadows with heavy equipment (tractor) (MH) and abandoned fields (AA). 


\section{Localities description:}

1. Dăbâca - Pâglișa: DPD - Pădurea Dumbrava (Dumbrava forest), mixed decidous forest; DFD hay meadow with shrubs, near Dumbrava forest;

2. Bădeşti (Fig. 2): $\mathrm{BMT}_{4}$ - hay meadow, traditionally mowed; $\mathrm{BMB}_{4}$ - hay meadow, mowed mechanically with Brielmaier mowers; $\mathrm{BMH}_{4}$ - hay meadow mowed mechanically with heavy equipment; $\mathrm{BAA}_{4}$ - hay meadow abandoned;

3. Chidea (Fig. 3): $\mathrm{CPE}_{1}$ - meadow with shrubs, extensively grazed; $\mathrm{CAA}_{1}$ - hay meadow abandoned;

4. Dăbâca (Fig. 4 and 5): DPC - Pădurea Ciungilor (Ciungilor forest), mixed deciduous forest; DFPC - hay meadow near Ciungilor forest; DLP - apple orchard, grazed; $\mathrm{DPE}_{3}$ - pasture, extensively grazed; $\mathrm{DPI}_{3}$ - pasture, intensively grazed;

5. Luna de Jos - Dealul Cocoşului (Cocoşului Hill): $\mathrm{LPE}_{2}$ - meadow with shrubs: Rosa, Crategus etc, extensively grazed; $\mathrm{LPI}_{2}$ - meadow, intensively grazed, currently with luxurious vegetation;

6. Luna de Jos - Răscruci (Fig. 6): $\mathrm{LMT}_{2}$ Fânaţul Domnesc, meadow traditionally mowed, but currently intensively grazed; $\mathrm{LMB}_{2}$ - Fânaţul Domnesc, meadow, mowed mechanically with Brielmaier mowers, now grazed; $\mathrm{LMH}_{2}$ - Fânaţul Sătesc, meadow, mowed mechanically with heavy equipment; LAA - Fânaţul Sătesc, hay meadow abandoned, now strongly grazed;

7. Deuşu (Fig. 7): DPS - mixed deciduous forest; DPP - meadow (hay meadow) near the forest;

8. Satu Lung (Fig. 8): $\mathrm{SLMT}_{3}$ - hay meadow, traditionally mowed; $\mathrm{SLMB}_{3}$ - hay meadow, mowed mechanically with Brielmaier mowers; $\mathrm{SLMH}_{3}$ hay meadow, mowed mechanically with heavy equipment; $\mathrm{SLAA}_{3}$ - hay meadow abandoned;

9. Borşa Cătun: $\mathrm{BCMT}_{1}$ - hay meadow, traditionally mowed; $\mathrm{BCMB}_{1}$ - hay meadow, mowed mechanically with Brielmaier mowers; $\mathrm{BCMH}_{1}$ - hay meadow, mowed mechanically with heavy equipment;

10. Fânaţele Clujului: $\mathrm{FCPE}_{4}$ - hay meadow with shrubs, extensively grazed;

11. Pădureni: $\mathrm{PPI}_{4}$ - pasture, intensively grazed, located in the vicinity of the site, near Fânaţele Clujului;

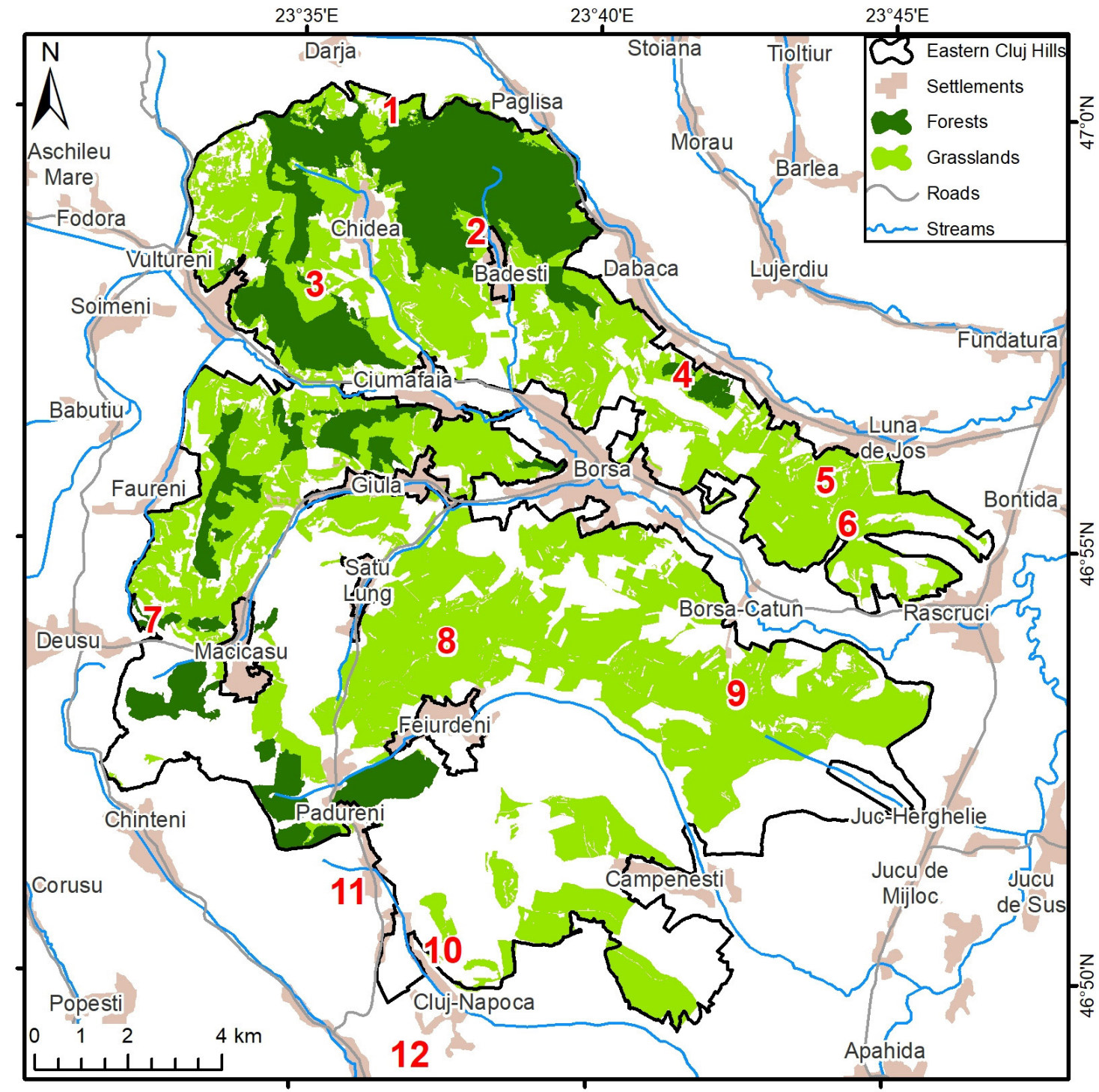

Fig. 1. Study areas in the Natura 2000 Site „Eastern Cluj Hills”: 1. Dăbâca - Pâglişa, 2. Bădeşti; 3. Chidea, 4. Dăbâca, 5. Luna de Jos - Dealul Cocoşului, 6. Luna de Jos - Răscruci, 7. Deuşu, 8. Satu Lung, 9. Borşa Cătun, 10. Fânaţele Clujului, 11. Pădureni, 12. Cluj-Napoca - Dealul Sfântu Gheorghe (map Andrei CRIŞAN and L.A. TEODOR). 


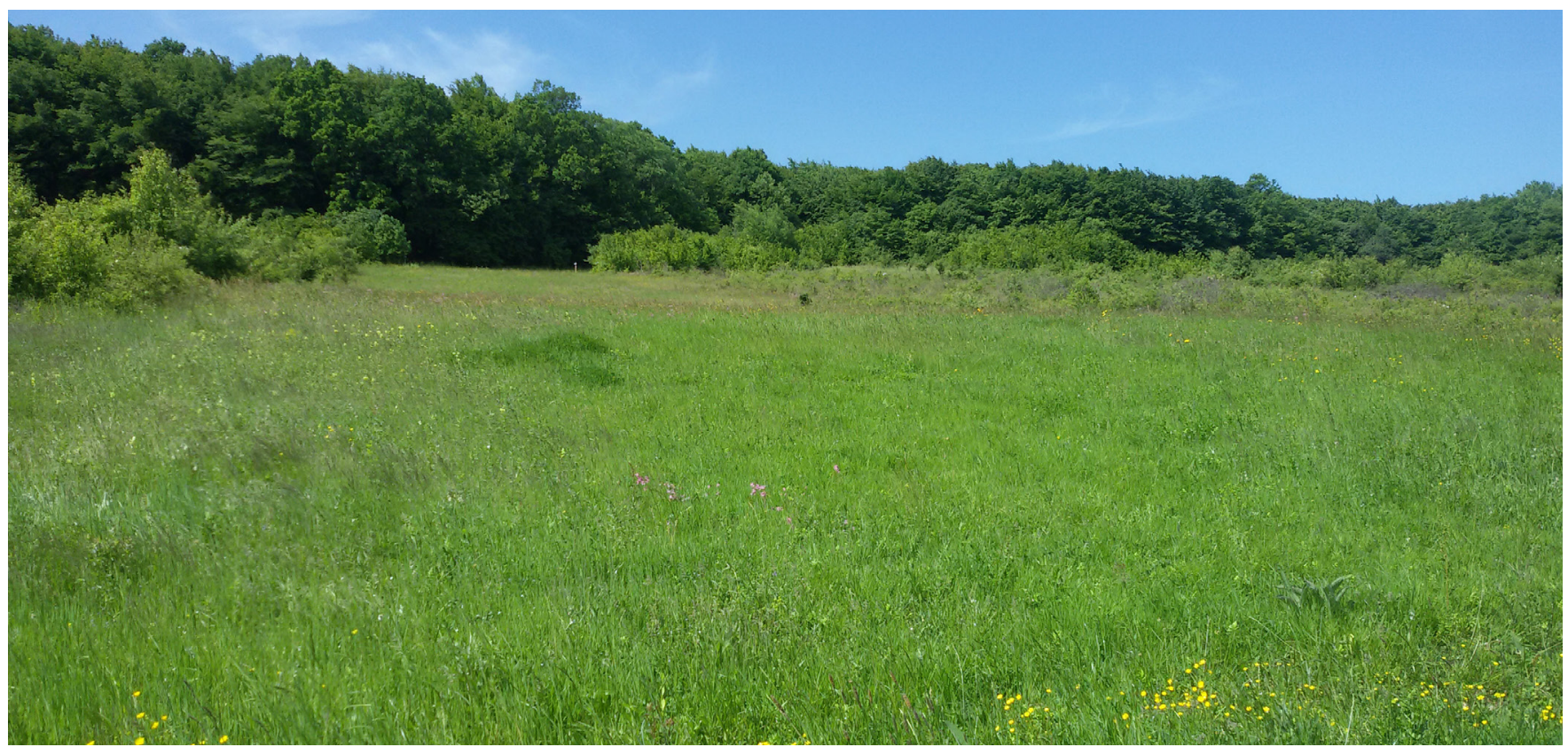

Fig. 2. Bădeşti, mechanically mowed hay meadow with Brielmaier mowers, photo: TEODOR L.A.

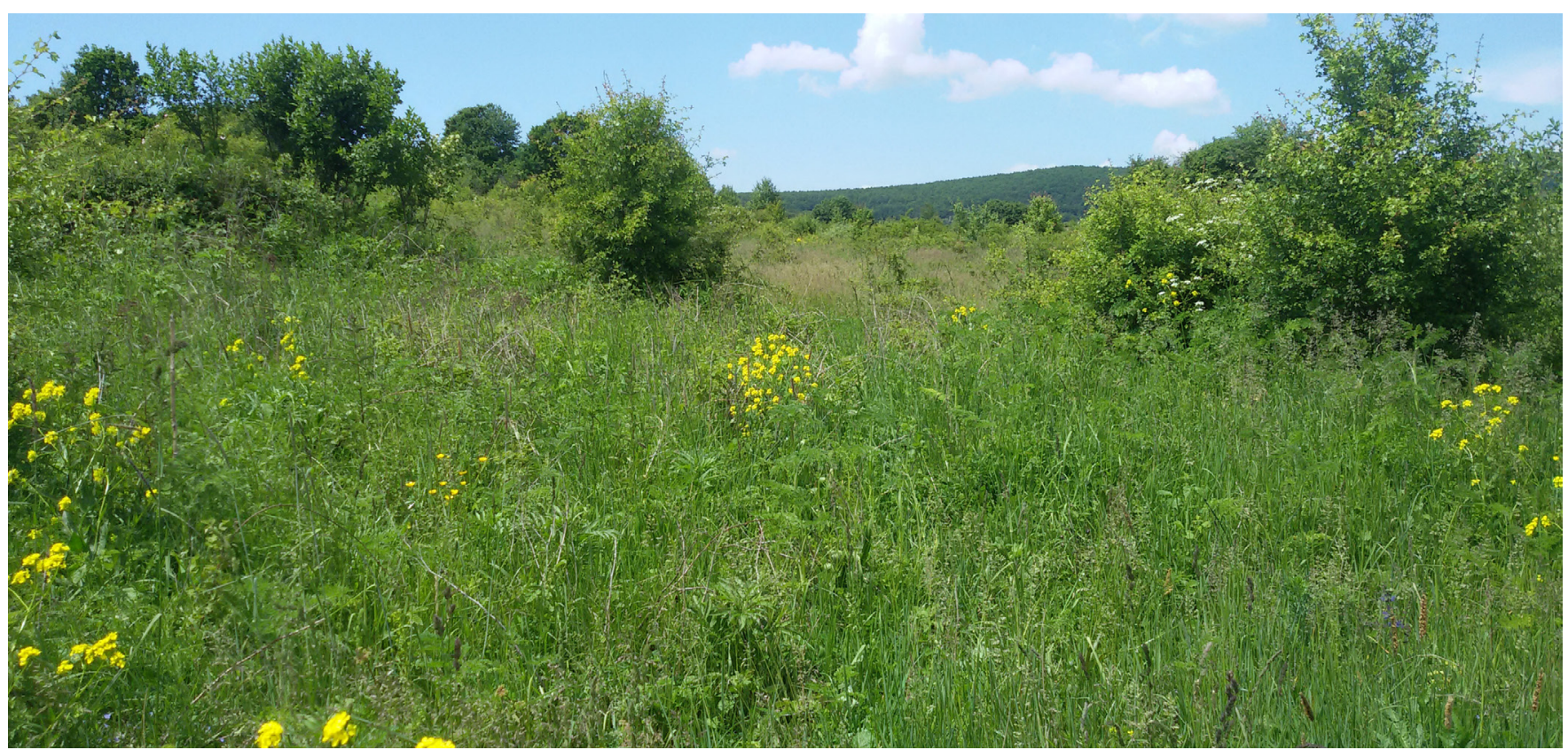

Fig. 3. Chidea, abandoned hay meadow with shrubs, photo: TEODOR L.A..

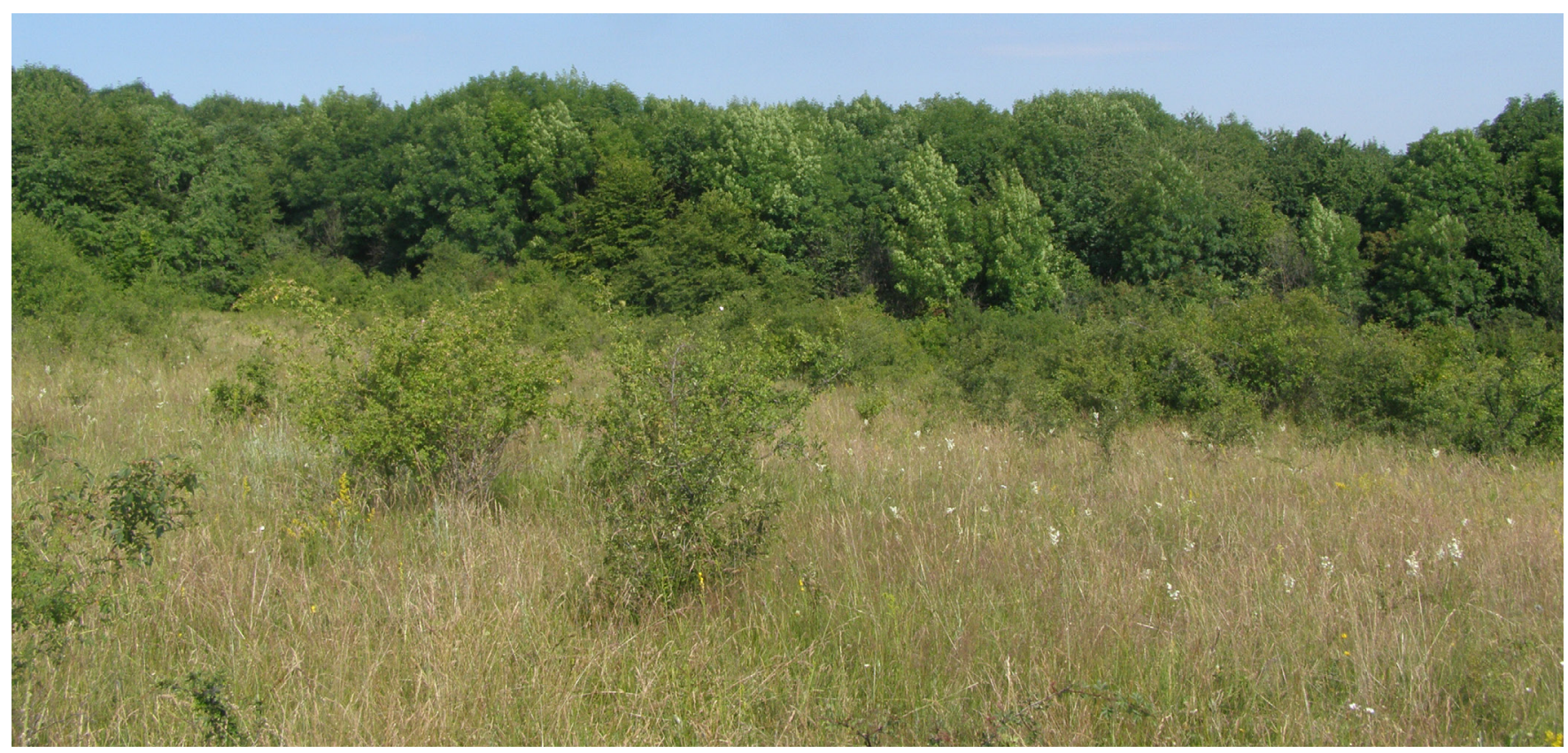

Fig. 4. Dăbâca, Ciungilor mixed deciduous forest and hay meadow near the forest, photo: TEODOR L.A. 


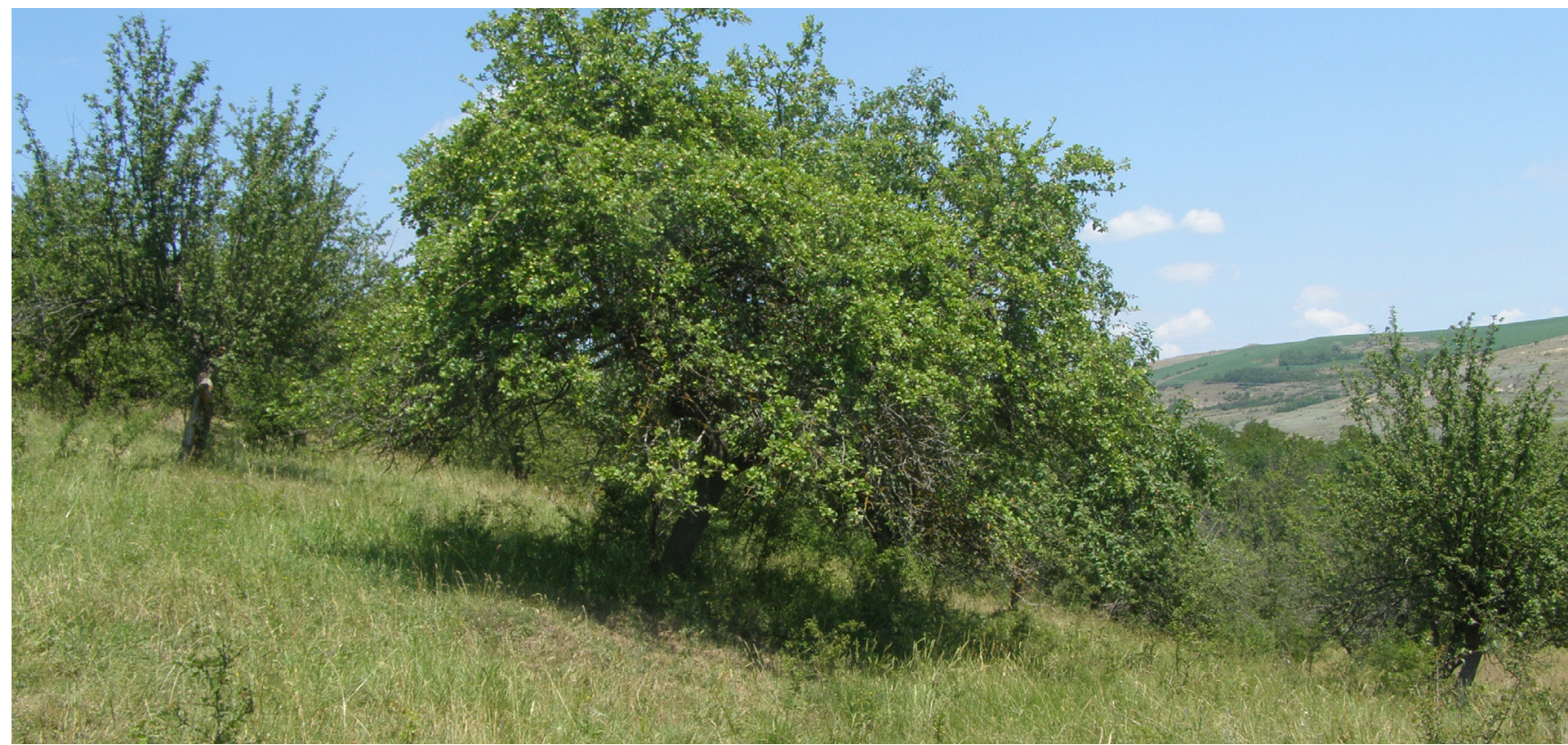

Fig. 5. Dăbâca, grazed apple orchard, photo: TEODOR L.A.

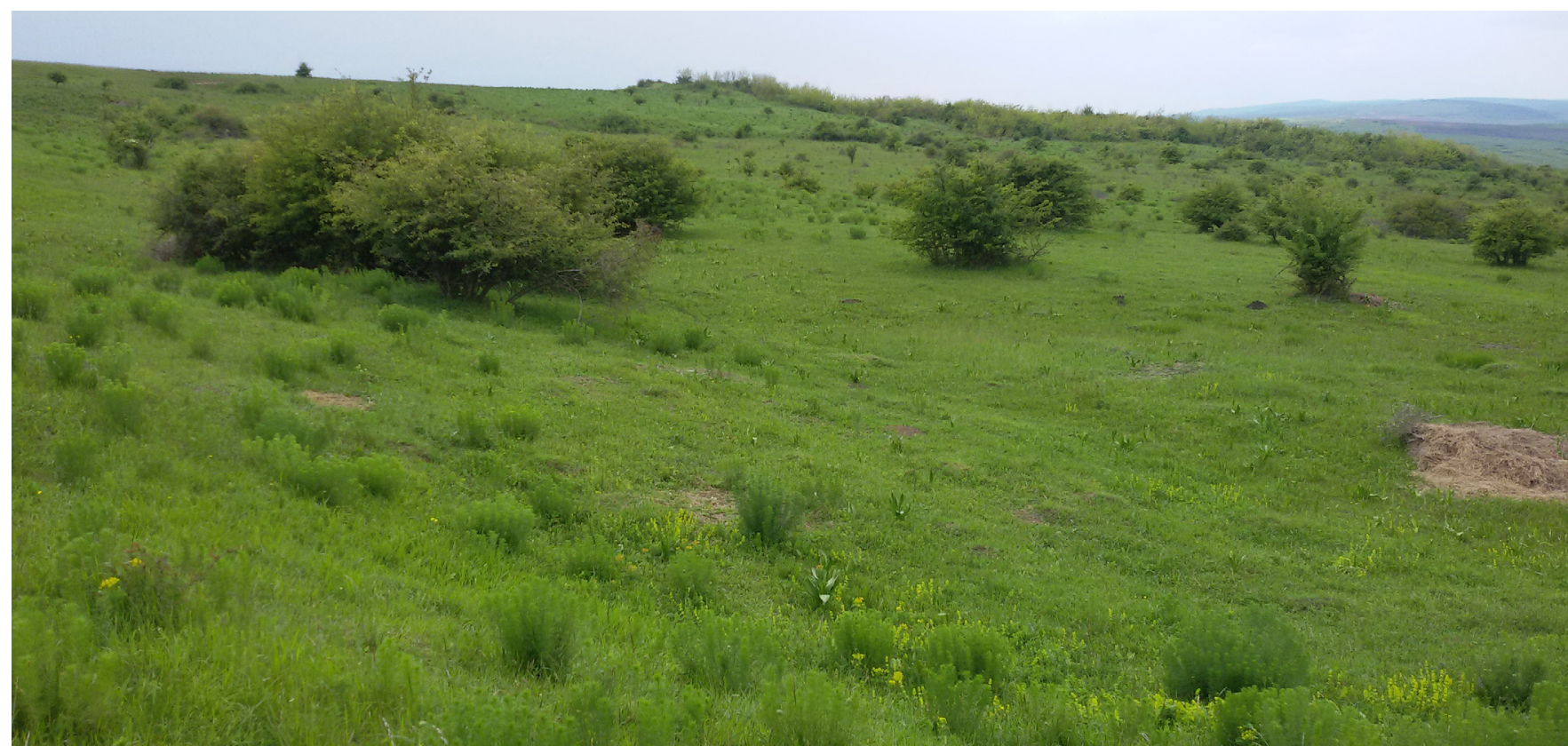

Fig. 6. Luna de Jos - Răscruci: Fânaţul Domnesc, mechanically mowed meadow with Brielmaier mowers, photo: TEodor L.A.

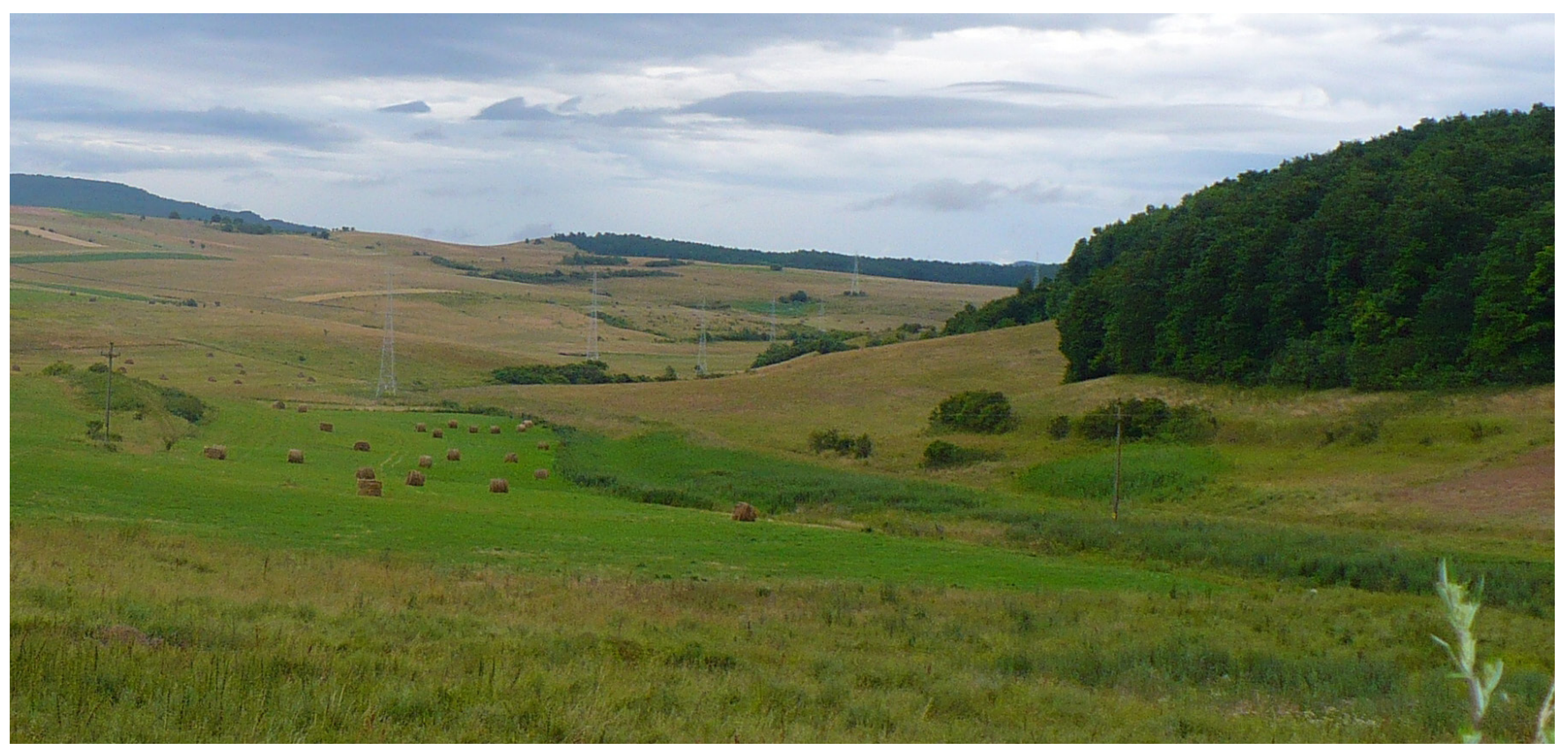

Fig. 7. Deuşu, mixed deciduous forest and meadows near the forest, photo: CRIŞAN A. 


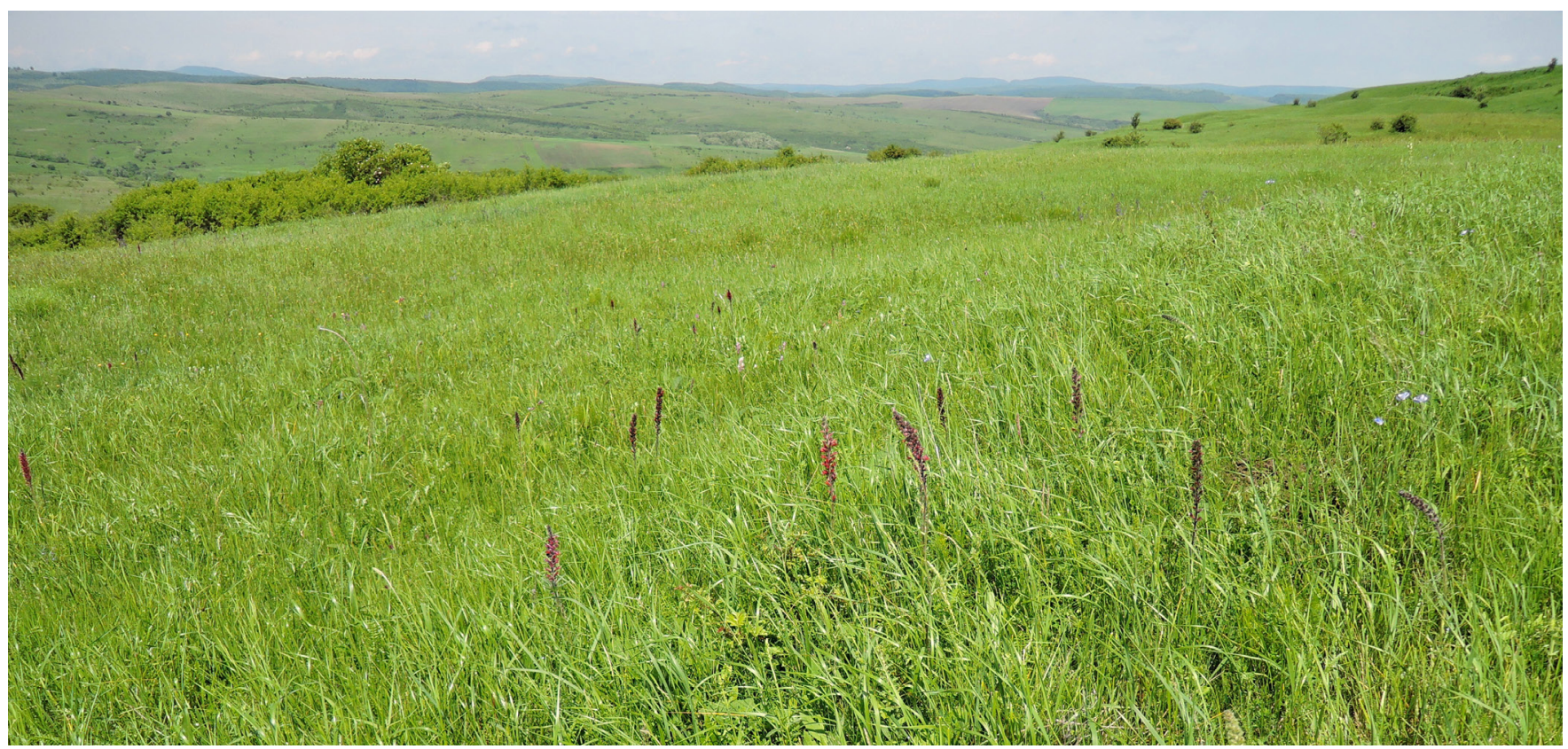

Fig. 8. Satu Lung, traditionally mowed hay meadow, photo: CRIŞAN A.

12. Cluj-Napoca - Dealul Sfântu Gheorghe (Sfântu Gheorghe Hill): DSPI ${ }_{1}$ - meadow with shrubs intensively grazed, located in the vicinity of the site, near Fânaţele Clujului.

\section{Material and methods}

Weevils were collected irregularly during 20142016: in June and August 2014, May and June 2015, and 2016. From trees and bushes they were sampled by shaking tree and shrub branches, using the umbrella net, and from meadows by sweeping plants with sweep net. Sifting the litter with an entomological sieve and directly from the vegetation by hand picking or using an entomological tweezers, weevils were additionally collected. A total of 1242 individuals were collected.

Beetles were dissected, kept and analyzed, using the stereo microscope OLYMPUS SZ51. For identification to the species level different keys for weevils determination were used (DIECKMANN 1980, 1988; Freude, HARde and LoHSE 1981, 1983; Behne 1994, 1998; Colennelli 2004; Borovec and Pelletier 2009; Skuhrovec 2009; SKuhrovec et al. 2010; RheinHeimer and Hassler 2010; CALDARA and Fogato 2013; STÜBEN et al. 2011, 2013, 2014, 2015). Based on Löbl and Smetana (2011, 2013) and Alonso - ZARAZAGa et al. (2017), the current nomenclature and systematics were established, and according to TEODOR and VLAD (2007) current distribution of weevils species in Romania were checked.

\section{Results}

We recorded 102 species in total (12 localities with 31 different biotopes) in the Nature 2000 Site „Eastern Cluj Hills” (Romania, Transylvania) (Table 1). Mecinus plantaginis is recorded for the first time from Romania and Mogulones larvatus, Argoptochus quadrisignatus, Lixus cylindrus and L. angustus are rare in the country (Table 1).

Mecinus plantaginis, Satu Lung, 20.V.2016, $\mathrm{SLMB}_{3}$ - hay meadow, mowed mechanically with Brielmaier mowers, one female collected by sweeping plants with sweep net, leg. and det. L. A.TeOdOR. Present in Hungary and Serbia (Alonso ZARAZAGA et al. 2017) and in Central Europe, as well as in Southern and Eastern Europe, in South-Eastern Russia, Mongolia and China (RHeINHeIMER and Hassler 2010, Caldara and Fogato 2013). Feed on Plantago media (Plantaginaceae).

Mogulones larvatus, Dăbâca, 11.VIII.2014, DFPC - hay meadow near Ciungilor forest, one male collected by sweeping plants with sweep net, leg. and det. L. A.TEODOR. In Romania has been found up to now in Transylvania: Piatra Craiului Mountains (Holdhaus and Deubel 1910), Sighişoara, Bazna, Râşnov, Şirnea (PETRI 1912), Şura Mare (ENDRöDI 1969), Băile Homorod, Nicoleşti (Podlussány and Kocs 1997), Cheile Vârghişului (Kocs 2013) and Banat: Herculane (ENDRÖDI 1969). Eurosiberian species (RHeinheImer and Hassler 2010, StüBEN et al. 2014). Feed on species of Pulmonaria and Echium (Boraginaceae).

Argoptochus (Argoptochus) quadrisignatus, Luna de Jos - Răscruci, 19.V.2016, LMB 2 - Fânaţul Domnesc, meadow, mowed mechanically with Brielmaier mowers, one male collected by shaking shrub branches, using the umbrella net, leg. and det. L. A.TEOdor. In Romania has been found by now only in two locations, one from Transylvania: Sânpetru near Brasov (PeTRI 1925/'26) and one from Moldavia: in the surroundings of Iaşi (MARCU 19441947). Distributed in Eastern Germany, Southern Poland, Czech Republic, Slovakia, Ukraine, Northern Black Sea (Russia), Republic of Moldova and 
Romania (StÜBEN et al. 2015). It is poliphagous species (Dieckmann 1980).

Lixus (Callistolixus) cylindrus, Satu Lung, 5.VI.2015, SLMT $_{3}$ - hay meadow, traditionally mowed, one male collected by sweeping plants with sweep net, leg. A. CrişAN, det. L. A.TeOdor. In Romania has been found by now in Transylvania: Sibiu, Guşteriţa (Hampe 1852, Bielz 1887, Petri 1912), Valea Serbuta near Şura Mare (Sibiu County) (SchNeIDER 1970, 1990), Aghireş (Sălaj County) (MerkL et al. 2016), Banat: Domogled (Herculane) (Kuthy 1900) and Crişana: Remeţi (Bihor County) (KuTHY 1900). Occur in the south of Central Europe, East, South - East and South of Europe (RHEINHEIMER and HASSLER 2010). Lives on species of Peucedanum and Laserpitium (Apiaceae).

Lixus (Ortholixus) angustus, Satu Lung, 22.VII.2016, SLAA 3 - hay meadow abandoned, one male collected by sweeping plants with sweep net, leg. A. Crişan, det. L. A.TeOdor. In Romania has been found by now in Transylvania: Hamba near Sibiu (Petri 1925/'26), Banat: Herculane (Marcu 1964), Crişana: Oradea (MARCU 1964) and Moldavia: Ponoare and „Eminescu forest” Ipoteşti (TEODOR and DĂNILĂ 1994, 1997, 2011). In contradiction with the above mentioned bibliographic data, in the recent Palearctic catalogs (LöBL and SMETANA 2011, 2013, Alonso - ZaraZAGA et al. 2017), is not specified the presence of this species in Romania, but only in some neighboring countries: Hungary and Ukraine. We put it on the list of Romanian weevil species (TEODOR and ANTONIE VlaD 2007), but with the wrong name: Lixus (Ortholixus) angustatus (Herbst, 1795) instead of $L$. (Ortholixus) angustus Herbst, 1795. Our record, in Satu Lung, confirm again the presence of this weevil in Romania. Polyphagous species occur in Europe and Western Asia (RHEINHEIMER and HASSLER 2010).

The most numerous in individuals are populations of Sciaphobus caesius (242 individuals), Larinus obtusus (226 individuals), Eusomus ovulum (154 individuals) and Foucartia ptochoides (132 individuals), some species of genera: Protapion, Sitona, Phyllobius and Polydrusus are also numerous (Table 1).

The most abundant are: Sciaphobus caesius collected in 27 biotopes at 11 localities, Eusomus ovulum - 27, 10 localities and Larinus obtusus - 24 biotopes at 11 localities.

The most richness and various weevil fauna occur in Bădeşti (42 species), followed by Satu Lung (33), Chidea (30), Dăbâca (29), Luna de Jos - Răscruci (29), Pădureni (24), Pădureni, PPI $_{4}$ - pasture intensively grazed (24), Bădeşti, $\mathrm{BAA}_{4}$ - hay meadow abandoned (21) and $\mathrm{BMB}_{4}$ - hay meadow, mowed mechanically with Brielmaier mowers (21). The most poor weevil fauna has been found in Dăbâca - Pâglişa (DFD) - hay meadow near Dumbrava Forest (2 species), Dăbâca $\left(\mathrm{DPE}_{3}\right)$ - pasture extensively grazed (2), Dăbâca Pâglişa (DPD) - Dumbrava mixed deciduous forest (3).
The richness of weevil species in other biotopes is between 5 and 19 (Table 1).

The results of our preliminary study show no differences between the richness and diversity of weevils depending on the type and degree of human impact in the meadows studied (Fig. 9). However, this requires further and more detailed and more intensive study.

\section{Discussion}

The weevils (102 species) that we recorded the Nature 2000 Site „Eastern Cluj Hills” and their diversity (Table 1) it is a preliminary good result if we compare it with those regarding weevils from other similar protected areas. For example, in the Zasavica Special Nature Reserve (Serbia) 86 weevil species were collected (PEŠIć et al. 2018), in Ječmeniště dry grasslands area (Czech Republic) 168 weevil species were recorded (STEJSKAL 2004) and 172 weevil species were recorded in Nature 2000 Site "Cusma" (TEODOR et al. 2010).

Our preliminary data (Fig. 9), have not confirmed the hypothesis that the diversity and richness of the weevil species should be higher in the traditionally mowed meadow, following those mechanically mowed with the light mowers (Brielmaier mowers) and those abandoned and lower in the mowed meadows with the heavy equipment, and that it should be higher in the extensive pastures and lower in the intensive pastures. For example, the traditional mowed meadow from Borşa Cătun has only 8 species, while the traditional mowed meadow from Bădeşti has 18 species. Some meadows, such as the one mechanically mowed with the Brielmaier mowers from Bădeşti (21 species), the abandoned meadow from Bădeşti (21 species) and the intensively grazed pasture from Pădureni ( 24 species) have more weevil species than the traditionally mowed meadows. The least weevil species were in the meadow extensively grazed in Dăbâca (2 species) while in the intensively grazed meadow of the same locality there were 9 species, and the majority of species were in the intensively grazed meadow in Pădureni (Fig. 9). Probably the floristic composition of each meadow is the main factor that influences the number of weevil species and not the different ways of mowing and grazing, as well as the abandonment of meadows. Diversity and number of weevil species recorded only in a short research period (102 species) and bibliographic data, which showing that some of the meadows on this Site have the largest floristic diversity in Europe (WILSON et al. 2012), suggests that the diversity and richness of weevil species in the Nature 2000 Site „Eastern Cluj Hills” is much larger, aspect which can be confirmed by further weevils research in this area. On the other hand, quantitative study should be carried out covering the entire growing season and a greater number of samples at each localities, which would also allow 


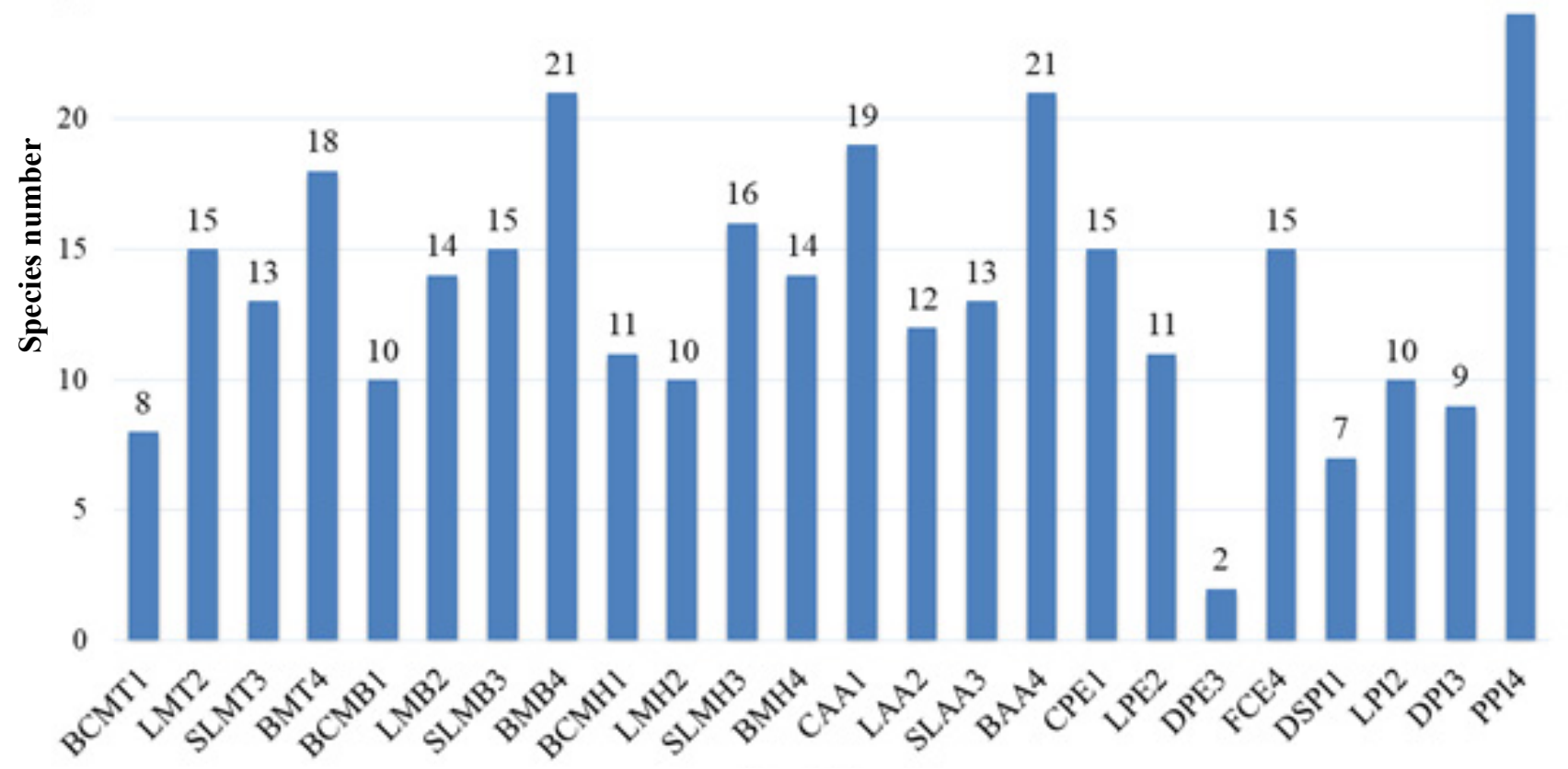

Investigated meadows

Fig. 9. Richness of weevil species in studied meadows of the Nature 2000 Site "Eastern Cluj Hills".

Abbreviations: $\mathbf{B A A}_{4}=$ Bădeşti, hay meadow 4, abandoned; $\mathbf{B M B}_{4}=$ Bădeşti, hay meadow 4, mechanically mowed with Brielmaier mowers; $\mathbf{B M H}_{4}=$ Bădeşti, hay meadow 4, mechanically mowed with heavy equipment; BMT $=$ Bădeşti, hay meadow 4, traditionally mowed; $\mathbf{B C} \mathbf{C} \mathbf{B}_{1}=$ Borşa Cătun, hay meadow 1, mechanically mowed with Brielmaier mowers; $\mathbf{B C M H}_{1}=$ Borşa Cătun, hay meadow 1 , mechanically mowed with heavy equipment; BCMT $=$ Borşa Cătun, hay meadow 1, traditionally mowed; CAA $=$ Chidea, hay meadow with shrubs 1 , abandoned; $\mathbf{C P E}=$ Chidea, meadow with shrubs 1 , extensively grazed; $\mathbf{D P E}_{3}=$ Dăbâca, pasture 3, extensively grazed; DPI $=$ Dăbâca, pasture 3, intensively grazed; DSPI $=$ Cluj, Dealul Sfântu Gheorghe, meadow with shrubs 1, intensively grazed; $\mathbf{F C P E}_{4}=$ Fânaţele Clujului, hay meadow with shrubs 4, extensively grazed; LAA $\mathbf{A}_{2}=$ Luna de Jos - Răscruci: Fânaţul Sătesc, hay meadow 2, abandoned, now strongly grazed; $\mathbf{L M B} \mathbf{B}_{2}=$ Luna de Jos - Răscruci: Fânațul Domnesc, hay meadow 2, mechanically mowed with Brielmaier mowers, now grazed; $\mathbf{L}_{\mathbf{M}} \mathbf{H}_{2}=$ Luna de Jos - Răscruci: Fânaţul Sătesc, hay meadow 2, mechanically mowed with heavy equipment; $\mathbf{L M T} \mathbf{2}_{2}=$ Luna de Jos - Răscruci, Fânaţul Domnesc, hay meadow 2, traditionally mowed, but currently intensively grazed; $\mathbf{L P E}_{2}{ }_{2}=$ Luna de Jos - Dealul Cocoşului, meadow with shrubs 2, extensively grazed; LPI ${ }_{2}=$ Luna de Jos - Dealul Cocoşului, meadow 2, intensively grazed, currently with luxurious vegetation; $\mathbf{P P I}_{\mathbf{4}}=$ Pădureni, pasture 4, intensively grazed; $\mathbf{S L A \mathbf { A } _ { \mathbf { 3 } } =}$ Satu Lung, hay meadow 3, abandoned; $\mathbf{S L M B}_{3}=$ Satu Lung, hay meadow 3, mechanically mowed with Brielmaier mowers; $\mathbf{S L M H}_{3}=$ Satu Lung, hay meadow 3, mechanically mowed with heavy equipment; SLMT $\mathbf{3}_{3}=$ Satu Lung, hay meadow 3 , traditionally mowed.

statistical analysis and then the hypothesis adopted at the beginning could be unambiguously maintained or refuted. These preliminary results of our study do not allow an unambiguous answer to the problem posed.

\section{Acknowledgements}

The authors bring their warmest thanks for help to the unknown reviewer who contributed to a significant improvement in the content and quality of the original version of the manuscript. The authors would like to thank their colleagues: Cristina CRAIOvEANU, Andrei CrişAN and Cristian Sitar, for their help in the field trips aiming at sampling and studying weevils alongside other insect groups from the Site. We also thank our colleague Andrei CRIŞAN for helping us with map and photographs of the investigated biotopes.

\section{Bibliography}

Alonso-Zarazaga M.A., Barrios H., Borovec R., Bouchard P., Caldara R., Colonnelli E., Gültekin L., Hlaváč P., Korotyaev B., Lyal C.H.C., Machado A., Meregalli M., Pierotti H., Ren L., SÁnchez-Ruiz M., Sforzi A., Silfverberg H., Skuhrovec J., TrÝzna
M., Velázquez de Castro A.J. and Yunakov N.N. (2017) Cooperative Catalogue of Palaearctic Coleoptera Curculionoidea. Monografías electrónicas S.E.A. 8: $1-729$.

Alonso-Zarazaga M.A. and Lyal C.H.C. (1999) A world catalogue of families and genera of Curculionoidea (Insecta: Coleoptera) (Excepting Scolytidae and Platypodidae). Entomopraxis, S. C. P., Barcelona, Spain.

BEHNE L. 1994. Superfamilie: Curculionoidea, pp. 181-298, 343-374. In: LoHSE G.A., Lucht W.H. (eds.): Die Käfer Mitteleuropas. 14: 3. Supplementband mit Katalogteil (Ergänzungen und Berichtigungen zu Band 6-8). Goecke \& Evers, Krefeld.

Behne L. (1998) Familie: Nemonychidae. Familie: Apionidae. Familie: Curculionidae, pp. 328-339. In: Lucht W.H., KLAusnitzer B. (Eds.): Die Käfer Mitteleuropas. 15: 4. Supplementband. Goecke \& Evers, Krefeld, Gustav Fischer, Jena.

BIELz E.A. (1887) Catalogus coleopterorum Transsylvaniae. Verh. Mittl. Siebenb. Ver. Naturw. Hermannstadt 37: 39114.

Borovec R. and Pelletier J. (2009) Revion of the genus Foucartia Jacquelin du Val, 1855 (Coleoptera: Cucurlionidae: Entiminae: Sciaphilini). Acta Soc. Zool Bohem. 73: 1-26.

Caldara R. and Fogato V. (2013) Systematics of the 
weevil genus Mecinus Germar, 1821 (Coleoptera: Curculionidae). I. Taxonomic treatment of the species. Zootaxa 3654(1): 1-105.

Colonnelli E. (2004) Catalogue of Ceutohynchinae of the World, with key to Genera (Insecta: Coleoptera: Curculionidae). Argania, Barcelona.

Crişan A., Popa V. and TeOdor L.A. (1999) Ecological study on some insect groups (Homoptera, Cicadina; Coleoptera, Chrysomelidae, Curculionoidea) from the Someşul Cald-Ic Ponor area. Analele Univ. Oradea, Fac. Biol. 6: 23-48.

DiECKMANN L. (1980) Beiträg zur Insekten der DDR: Coleoptera Curculionidae (Brachycerinae, Otiorhynchinae, Brachyderinae). Beitr. Ent., Berlin 30(1): 145-310.

DieCKMANn L. (1988) Beiträge zur Insektenfauna der DDR: Curculionidae (Curculioninae: Ellescini, Acalyptini, Tychiini, Anthonomini, Curculionini). Beitr. Ent. Berlin 38(2): 365-468.

ENDRÖDI S. (1969) Az ormányosbogarac (Curculionidae) kárpátmedencei lelöhelyadatai IV. (Informations about the weevils (Curculionidae) of the Carpathian Basin IV.) Folia Entomologica Hungarica, Budapest 22(13): 311348 (in Hungarian).

Guşă D.N. (2005) Date bio-ecologice asupra speciilor de Curculionide (Coleoptera, Curculionoidae) din Parcul Naţional Piatra Craiului-Jud. Braşov (Bio-ecological date on weevils (Coleoptera, Curculionidae), in the Piatra Craiului National Park). Studii şi Comunicări, Compl. Muz. Şt. Nat. „Ion Borcea” 20: 91-97 (in Romanian).

Guşă D.N. and Blaga T. (2006) The population dynamic of the family Curculionidae (Insecta - Coleoptera) in the Piatra Craiului National Park - Romania. In: IUFRO Working Party 7.03.10. Proceedings of the Workshop 2006, Gmunden: 292-299.

Freude H., Harde K.W. and Lohse G.A. (eds.) (1981, 1983) Die Käfer Mitteleuropas. 10, 11. Goecke \& Evers. Krefeld.

Hampe H. (1852) Beitrag zur Käferfauna Siebenbürgens. Verh. Mitt. Siebenb. Ver. Naturw. Hermannstadt 3(9): 140-141.

Holdhaus K. and Deubel F. (1910) Unterschungen über die Zoogeographie der Karpaten. Gustav Fischer, Jena.

Kocs I. (1996) Kiegészités Kovászna megye Curculionoidea faunájához az 1995-96-os év gyüjtései alapjá. (Additional data regarding the knowledge of Curculionids from Covasna County based on the research carried out between 1995-1996). Acta: 43-48 (in Hungarian).

Kocs I. (2013) Adatok a Vargyas-Szoros és környékének ormányosalkatú bogárfaunájához (Coleoptera: Curculionoidea) (Data concerning the Curculionoidea (Coleoptera) fauna of the Vârghiş Pass and its surroundings). Acta Siculica: 75-83 (in Hungarian).

KNUTELSKI S. (2005) Różnorodność, ekologia i chorologia ryjkowców rezerwatu biosfery „Tatry” (Coleoptera: Curculionoidea) (Diversity, ecology and chorology of weevils of the "Tatry" biosphere reserve (Coleoptera: Curculionoidea)). Monografie Faunistyczne, 23. Wydawnictwa Instytutu Systematyki i Ewolucji Zwierząt, Polskiej Akademii Nauk, Kraków (in Polish).

KNUTElSKi S. and Surowiak A. (2011) Nowe gatunki ryjkowców (Coleoptera: Apionidae, Curculionidae) w Pienińskim Parku Narodowym. (New weevil species (Coleoptera: Apionidae, Curculionidae) in the Pieniny Natonal Park (S Poland). Chrońmy Przyr. Ojcz. 67 (2): 147-154 (in Polish).

Kuthy D. (1900) Coleoptera, pp: 1-214. In: Fauna Regni Hungariae, 3, Budapest.
LAWRENCE J.F. and Newton J. (1995) Families and subfamilies of Coleoptera, pp.779-1006, în: PAKALuK J. and SLIPINSKi S.A. (eds.): Biology, Phylogeny and Classification of Coleoptera, Museum i Instytut Zoologii PAN, Warszawa.

Löbl I. and Smetana A. (eds.) (2011, 2013) Catalogue of Palaearctic Coleoptera. 7 (Curculionoidea I) and 8 (Curculionoidea II). Leiden, Brill, Boston.

MARCU O. (1944-1947) Beitrag zur Curculioniden-Fauna der Moldau. Ann. Sci. de L'Univ. de Jassy 30(1-2): 5682.

MARCU O. (1964) Contribuţii la cunoaşterea faunei coleopterelor din Transilvania (Contributions to the knowledge of the beetles fauna from Transylvania). Studia Univ. 'Babeş-Bolyai", Biologia 5(2): 75-88 (in Romanian).

MAZur M. (2002) The distribution and ecology of weevils (Coleoptera: Nemonychidae, Attelabidae, Apionidae, Curculionidae) in western Ukraine. Acta zoologica cracoviensia 45(3): 213-244.

MAZur M.A. (2011) Weevils (Coleoptera: Curculionoidea) of the Stobrawski Landscape Park. Polish Journal of Entomology 80 (2): 321-342.

Merkl O., NÉmeth T. and Podlussány A. (2016) Beetles from Sălaj County, Romania (Coleoptera, excluding Carabidae). Studia Universitatis "Vasile Goldiş", Seria Ştiinţele Vieţii 26 (supplement 1): 5- 58.

PEŠIĆ S. (2002) Weevils (Curculionoidea) of the National Park Tatra (the first contribution). Acta entomologica serbica 7(1/2): 29-39.

Pešić S. (2014) A review of weevils (Coleoptera, Curculionoidea) in the Zasavica Special Nature Reserve (Serbia). North-Western Journal of Zoology 10 (2): 280-292.

Pešić S. Vukajlović F., Tot I. 2018. A preliminary study of the summer aspect of weevil (Coleoptera: Curculionoidea) fauna of the Ovčar-Kablar Gorge (Western Serbia). Acta Entomologica Serbica 23(2): 1-14.

Petri K. (1912) Siebenbürgens Käferfeuna auf Grund ihrer erfaschung bis Jahre 1911. Jos Drotleff, Hermannstadt.

Petri K. (1925/26) Ergänzungen und Berichtigungen zur Käferfauna Siebenbürgens 1912. Verh. Mittl. Siebenb. Ver. Naturw. Hermannstadt 75(76): 165-206.

Podlussány A. (1981) The Apionidae (Coleoptera) fauna of the Hortobágy National Park, pp. 187-190. In: MAHUNKA S. (ed.): The Fauna of the Hortobágy National Park, Acad. Kiadò, Budapest.

PodlussánY A. (1986) Apionidae (Coleoptera) from the Kiskunság National Park, pp. 191-195. In: MAHUNKA S. (ed.): The Fauna of the Kiskunság National Park, Akad. Kiadò, Budapest.

Podlussány A. 1992. A Béda-Karapancsa Tájvédelmi körzet Rhynchophora faunája (The Rhynchophora fauna of the Beda-Karapancsa Nature Reserve). Dunátúli Dolg. Term. tud. Sorozat. Pécs 6: 141-154 (in Hungarian).

Podlussány A. and Kocs I. (1995) Kovászna megye Curculionoidea faunájának alapvetése (Contributions to knowledge of Curculionoidea fauna in Covasna County). Acta, Muz. Sec. al Ciucului, Muz. Naţ. Secuiesc: 57-71 (in Hungarian).

PodlussánY A. and Kocs I. (1997) Hargita megye Curculionoidea faunájának alapvetése (Contributions to the knowledge of Curculionoidea fauna in Harghita County). Acta: 1-22 (in Hungarian).

Pop G.P. (2012) Depresiunea Transilvaniei. Ediţia a doua revizuită şi adăugită (Depression of Transylvania. Second edition revised and added). Presa Universitară Clujeană, Cluj-Napoca.

Procheş Ş. (1998) Superfamily Curculionoidea 
(Coleoptera) in Maramureş (Romania). Trav. Mus. natl. Hist. nat. "Grigore Antipa” 40: 525-545.

Rákosy L., CRIȘAN A. and Craioveanu C. (2018) Beneficiile naturii în situl Natura 2000 "Dealurile Clujului de Est" (The Benefits of Nature in the Natura 2000 Site "Eastern Cluj Hills"). PENSOFT.

RHEINHEIMER J. and HASSLER M. (2010) Die Rüssekäfer Baden - Württembergs. Verlag regionalkultur Heidelberg, Basel.

SKuHrovec J. (2009) Digital-Weevil-Determination for Curculionoidea of West Palaearctic. Transalpina: Hypera / Limobius / Metadonus (Hyperinae: Hyperini). SNUDEBILLER, Studies on taxonomy, biology and ecology of Curculionoidea, CURCULIO-Institute, Mönchengladbach 10: 39-47.

Skuhrovec J., Gosik R. and Stejskal R. (2010) DigitalWeevil-Determination for Curculionoidea of the West Palearctic: Transalpina: Brachypera/Donus (Hyperinae: Hyperini). SNUDEBILLER. Studies on taxonomy, biology and ecology of Curculionoidea, CURCULIOInstitute, Mönchengladbach 11: 102-108.

StejSKAL R. (2004) Contribution to the knowledge of beetles (Coleoptera) of dry grasslands - weevils (Curculionoidea) of ječmeniště near Znojmo (Southern Moravia). Entomofauna carpathica 16: 74-82.

Stüben P.E., BAYer Ch., Sprick P. and Behne L. (2011) Digital-Weevil-Determination for Curculionoidea of the West Palearctic: Transalpina: Polydrusus (Entiminae: Polydrusini). SNUDEBILLER. Studies on taxonomy, biology and ecology of Curculionoidea, CURCULIOInstitute, Mönchengladbach 12: 12-24.

StüBen P.E., Müller G., Krátký J., Bayer Ch., Behne L. and Sprick P. (2013) Digital-Weevil-Determination for Curculionoidea of the West Palearctic: Transalpina: Ceutorhynchinae (2. part). (Ceuthorhynchini: Amalorrhynchus, Drupenatus Poophagus, Coeliodes, Pseudocoeliodes, Coeliodinus, Eucoeliodes, Neoxyonyx, Thamiocolus, Micrelus, Zacladus, Phrydiuchus, Stenocarus, Nedyus, Ceutorhynchus: Marklissus). SNUDEBILLER: Studies on taxonomy, biology and ecology of Curculionoidea, CURCULIOInstitute, Mönchengladbach 14: 1-24.

StüBEN P.E., Müller G., MÜller, U., KrÁtKÝ J., Bayer Ch., Behne L., Sprick P. 2014. DigitalWeevil-Determination for Curculionoidea of the West Palearctic: Transalpina: Ceutorhynchinae (3. part). (Ceutorhynchini: Datonychus, Ethelcus, Glocianus, Hadroplontus, Microplontus, Mogulones, Mogulonoides, Neoglocianus, Oprohinus, Parethelcus, Prisistus, Ranunculiphilus). SNUDEBILLER: Studies on taxonomy, biology and ecology of Curculionoidea, CURCULIO-Institute, Mönchengladbach 15: 1-25.

StüBen P.E., BAYer Ch., BAHr F., SPrick P., Behne L. (2015) Digital-Weevil-Determination for Curculionoidea of the West Palearctic: Transalpina: Phyllobiini. SNUDEBILLER. Studies on taxonomy, biology and ecology of Curculionoidea, CURCULIOInstitute, Mönchengladbach 16: 1-13.

SCHNEIDER E. (1970) Câteva elemente sudice şi estice în entomofauna colinelor stepice din împrejurimile Sibiului (Some southern and eastern elements in the entomofauna of the steppe hills in the surroundings of Sibiu). Muz. Brukenthal, Sibiu, Stud. Comunic. Şt. nat. 15: 279-286 (in Romanian).

SCHNEIDER E. (1990) Entomofauna biocenozelor stepice de pe Colinele Neogene din Nord-Estul Depresiunii Sibiului (Entomofauna of steppe biocenoses on the Neogene Hills from North-East of Sibiu Depression). Teză de doctorat (Doctoral thesis). Univ. din Cluj-Napoca, Fac. de Biologie, Geografie şi Geologie (in Romanian).
TeOdor L.A. (1993a) Contribuţii la cunoaşterea Curculionidelor (Coleoptera) din Delta Dunării (Contributions to the knowledge of weevils (Coleoptera) from the Danube Delta). Anal. Ştiinţ. Inst. Delta Dunării, Tulcea 2: 193-196 (in Romanian).

TeOdor L.A. (1993b) Contribuţii la studiul curculionidelor (Coleoptera: Curculionidae) din Cheile Turzii (Contributions to the study of weevils (Coleoptera: Curculionidae) from Turda Gorges). Bul. inf. Soc. lepid. rom., Cluj-Napoca 4(4): 215-222 (in Romanian).

Teodor L.A. and Antonie Vlad I. (2007) Suprafamilia Curculionoidea (Superfamily Curculionoidea), pp: 148-168. In: Moldovan O.T., Cîmpean M., Borda D., IEPURE S. and ILIE V. (eds.). Lista faunistică a României (specii terestre şi de apă dulce) (The faunistic list of Romania (terrestrial and freshwater species)), Casa Cărţii de Ştiinţă, Cluj-Napoca. (in Romanian)

TeOdor L.A. and Crişan A. (1996) Contributions to the knowledge of snout beetles (Coleoptera, Curculionidae) from „Scăriţa Belioara" Botanical Reservation (Romania). Bul. inf. Soc. lepid. rom., Cluj-Napoca 7(12): 151-156.

Teodor L.A. and CRişAn A. (2002) The snout-beetle fauna (Coleoptera, Curculionoidea) from the area Cheile Someşului Cald- Ic Ponor (Romania), pp: 7178. In: ToMESCU N. and PopA V. (eds.). In memoriam "Professor Dr. Doc. Vasile Gh. Radu" corresponding member of Romanian Academy of Sciences, Presa Universitară Clujeană.

TeOdor L.A. and CRIŞAN M. (2010) Snout-beetles (Coleoptera, Curculionoidea) from the Colibiţa area (Bârgău Mountains, Romania). Studia UBB. Biologia, Cluj-Napoca 55(2): 15-38.

Teodor L.A. Crişan M. and Colonnelli E. (2010) Curculionoide din situl Natura 2000 Cuşma (Weevils from Nature 2000 site Cuşma), pp: 192-215. In: Proorocu M., Beldean P. and Crişan A. (eds.). Situl Natura 2000 Cuşma (Nature 2000 site Cuşma), Ed. RISOPRINT, Cluj-Napoca (in Romanian).

TeOdor L.A., Crişan A. and Nistor L. (2001) Studies on the snout-beetle fauna (Coleoptera: Curculionoidea) from Poşaga de Sus- Belioara Valley area, Apuseni Mountains, Romania. Bul. inf. Soc. lepid. rom., ClujNapoca 12(1-4): 219-230.

Teodor L.A., Crişan A., Popa V. and Cojocneanu R. (1999) Curculionoidea (Coleoptera) fauna in the „Cheile Someşului Cald” area, Romania. Bul. inf. Soc. lepid. rom., Cluj-Napoca 10(1-4): 137-145.

TeOdor L.A., CRIŞAN A. and SEFFER B. (2000) Studies on snout-beetles fauna (Coleoptera, Curculionoidea) from "Cheile Turului", district of Cluj-Romania. Bul. inf. Soc. lepid. rom., Cluj-Napoca 11(1-4): 139-152.

TEODOR L. and DĂNILĂ I. (1994) Curculionide din județele Botoşani şi Suceava (Coleoptera: Curculionidae) (Weevils from Botosani and Suceava counties (Coleoptera: Curculionidae)). Bul. inf. Soc. lepid. rom., Cluj-Napoca 5(3-4): 281-290 (in Romanian).

TEODOR L.A. and DĂNILĂ I. (1997) The Curculionoidea (Coleoptera) fauna of the Botanical Natural Reserve „Codrul Eminescian Ipoteşti” (Botoşani district, Romania). Bul. inf. Soc. lepid. rom., Cluj-Napoca 8(34): 247-251.

TeOdor L.A. and DĂNILĂ I. (2011) Biodiversitatea curculionidelor (Coleoptera, Curculionoidea) din partea de Nord a Moldovei (România) (Biodiversity of weevils (Coleoptera, Curculionoidea) from northern part of Moldova (Romania)), pp: 101-114. In: Brudea V., Duduman M.L. and RÁKosy L. (eds.). Volumul de lucrări al Simpozionului „Biodiversitatea şi Managementul Insectelor din România”, Suceava, 
24-25 septembrie 2010, În memoria entomologului bucovinean Ioan Nemeş (The volume of works of the Symposium „Biodiversity and Insect Management in Romania", Suceava, September 24-25, 2010, In memory of the Bukovinian entomologist Ioan Nemeş), Ed. Univ. „STtefan cel Mare”, Suceava (in Romanian).

Teodor L.A. and Manole T. (1996) Noi contribuţii la cunoaşterea curculionidelor din Rezervaţia Biosferei „Delta Dunării” (New contributions to the knowledge of weevils from the Danube Delta Biosphere Reserve
(Coleoptera: Curculionidae)). Bul. inf. Soc. lepid. rom., Cluj-Napoca 7(3-4): 261-269.

TeOdor L.A. and MiLin V.Ş. (2013) Weevils (Coleoptera: Curculionidea) from the southern part of Retezat National Park and the Domogled-Cerna Valley National Park, Romania. Bul. inf. Entomol. Cluj-Napoca 24: 4452.

Wilson J.B., Peet R.K., Dengler J. and Pärtel M. (2012) Plant species richness: the world records. Journal of Vegetation Science 23: 796-802.
Lucian Alexandru TEODOR

Department of Taxonomy and Ecology Babeș-Bolyai University, Clinicilor 5-7 Cluj-Napoca, RO-400006, Romania E-mail: lucianteodor@yahoo.com teodor.lucian@ubbcluj.ro

Dragomir - Cosmin DAVID Department of Taxonomy and Ecology Babeș-Bolyai University, Clinicilor 5-7 Cluj-Napoca, 400006, Romania E-mail: davidcosmin18@yahoo.com
Alexandru CRIŞAN

Department of Taxonomy and Ecology Babeș-Bolyai University, Clinicilor 5-7 Cluj-Napoca, RO-400006, Romania

E-mail: crisan.alexandru@ubbcluj.ro

Received: 15.11 .2019

Accepted: 30.11 .2019

Published online: 31.12.2019

Published: 31.12.2019

Online article number: ER23201905
Mihaela ONIȘA

Medical Analysis Laboratory S.C.

Biomedica-Nova S.R.L

Constructorului 4, Sighetu Marmaţiei

Maramureş, Romania

E-mail: mihaela_popan94@yahoo.com 
Table 1. Weevil species recorded in the Nature 2000 Site "Eastern Cluj Hills" in 2014-2016

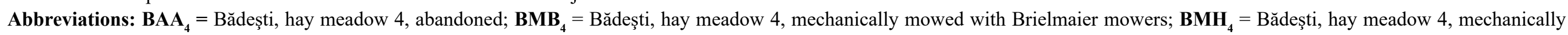

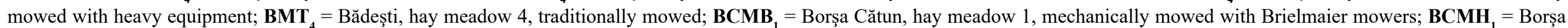

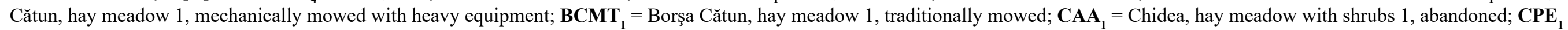

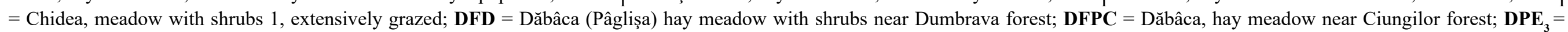

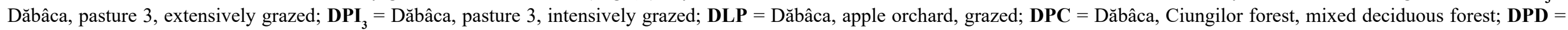

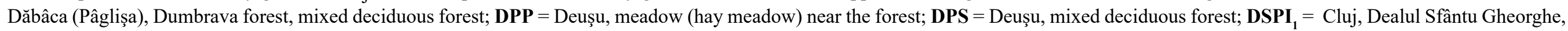

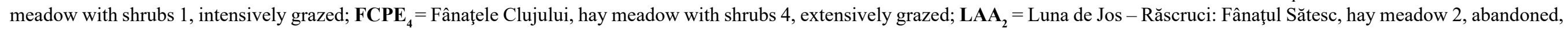

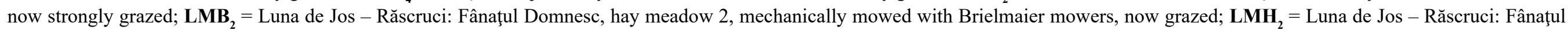

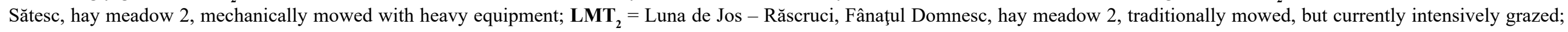

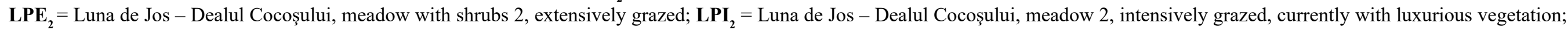

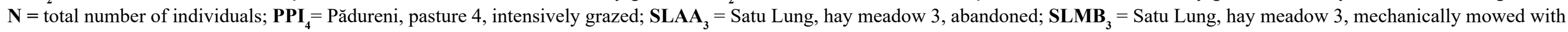

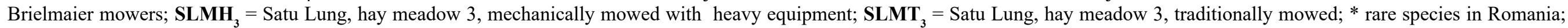
** new for Romanian fauna.

\begin{tabular}{|c|c|c|c|c|}
\hline \multirow[t]{5}{*}{$\begin{array}{l}\text { Nr. } \\
\text { crt. }\end{array}$} & Taxa & Date & $\mathbf{N}$ & $\begin{array}{c}\text { Localities / } \\
\text { biotopes }\end{array}$ \\
\hline & Superfamily Curculionoidea & & & \\
\hline & Family Attelabidae & & & \\
\hline & Subfamily Attelabinae & & & \\
\hline & Tribe Apoderini & & & \\
\hline \multirow[t]{2}{*}{1} & $\begin{array}{l}\text { Apoderus (Apoderus) coryli } \\
\text { LINNAEUs, } 1758\end{array}$ & 19.VI.2014 & 1 & DPC \\
\hline & Tribe Attelabini & & & \\
\hline \multirow[t]{3}{*}{2} & Attelabus nitens SCOPOLI, 1763 & 19.VI.2014 & 2 & DPD, DFD \\
\hline & Subfamily Rhynchitinae & & & \\
\hline & Tribe Rhynchitini & & & \\
\hline 3 & $\begin{array}{l}\text { Involvulus (Teretriorhynchites) } \\
\text { pubescens FABRICIUS, } 1775\end{array}$ & 20.V.2016 & 1 & $\mathrm{SLMH}_{3}$ \\
\hline \multirow[t]{6}{*}{4} & Neocoenorhinus & 19.V.2016 & 4 & $\mathrm{LPI}_{2}, \mathrm{LAA}_{2}$ \\
\hline & (Neocoenorhinus) germanicus & 20.V.2016 & 3 & $\mathrm{SLAA}_{3}, \mathrm{SLMH}_{3}$ \\
\hline & HERBST, 1797 & 26.V.2016 & 2 & $\mathrm{BAA}_{4} \mathrm{CAA}_{1}$ \\
\hline & Family Brentidae & & & \\
\hline & Subfamily Apioninae & & & \\
\hline & Tribe Apionini & & & \\
\hline 5 & $\begin{array}{l}\text { Alocentron curvirostre } \\
\text { GYLLENHAL, } 1833\end{array}$ & 19.V.2016 & 1 & $\mathrm{LMB}_{2}$ \\
\hline
\end{tabular}

\begin{tabular}{|c|c|c|c|c|}
\hline $\begin{array}{l}\text { Nr. } \\
\text { crt. }\end{array}$ & Taxa & Date & $\mathbf{N}$ & $\begin{array}{c}\text { Localities / } \\
\text { biotopes }\end{array}$ \\
\hline 6 & $\begin{array}{l}\text { Apion cruentatum } \\
\text { WALTON, } 1844\end{array}$ & 26.V.2016 & 2 & $\mathrm{BMB}_{4}, \mathrm{CPE}_{1}$ \\
\hline 7 & $\begin{array}{l}\text { Aspidapion (Koestlinia) aeneum } \\
\text { FABRICIUS, } 1775\end{array}$ & 21.VI.2016 & 1 & $\mathrm{FCPE}_{4}$ \\
\hline 8 & $\begin{array}{l}\text { Ceratapion (Echinostroma) } \\
\text { basicorne ILLIGER, } 1807\end{array}$ & 19.V.2016 & 1 & $\mathrm{LMB}_{2}$ \\
\hline \multirow[t]{2}{*}{9} & \multirow{2}{*}{$\begin{array}{l}\text { Catapion pubescens } \\
\text { KIRBY, } 1811\end{array}$} & 19.VI.2014 & 1 & DFPC \\
\hline & & 20.V.2016 & 1 & $\mathrm{SLAA}_{3}$ \\
\hline \multirow[t]{2}{*}{10} & \multirow[t]{2}{*}{ Catapion seniculus KIRBY, 1808} & 20.V.2016 & 2 & $\mathrm{PPI}_{4}$ \\
\hline & & 26.V.2016 & 2 & $\mathrm{BMT}_{4}^{4}, \mathrm{BMH}_{4}$ \\
\hline 11 & $\begin{array}{l}\text { Cyanapion (Cyanapion) } \\
\text { columbinum GERMAR, } 1817\end{array}$ & 19.VI.2014 & 1 & DFPC \\
\hline \multirow[t]{2}{*}{12} & $\begin{array}{l}\text { Eutrichapion (Cnemapion) } \\
\text { vorax HERBST, } 1797\end{array}$ & 19.V.2016 & 1 & $\mathrm{LAA}_{2}$ \\
\hline & & 26.V.2016 & 2 & $\mathrm{FCPE}_{4}, \mathrm{BMH}_{4}$ \\
\hline 13 & $\begin{array}{l}\text { Eutrichapion (Eutrichapion) } \\
\text { viciae PAYKUL, } 1800\end{array}$ & 26.V.2016 & 1 & $\mathrm{CAA}_{1}$ \\
\hline
\end{tabular}

Alocentron curvirost 


\section{Taxa}

14 Eutrichapion (Psilocalymma) punctiger PAYKULL, 1792

15 Hemitrichapion (Dimesomyops) pavidum GERMAR, 1817

\begin{tabular}{|c|c|c|c|c|}
\hline $\begin{array}{l}\text { Nr. } \\
\text { crt. }\end{array}$ & Taxa & Date & $\mathbf{N}$ & $\begin{array}{c}\text { Localities / } \\
\text { biotopes }\end{array}$ \\
\hline \multirow[t]{5}{*}{14} & \multirow{5}{*}{$\begin{array}{l}\text { Eutrichapion (Psilocalymma) } \\
\text { punctiger PAYKULL, } 1792\end{array}$} & 19.VI.2014 & 2 & DPP, DFPC \\
\hline & & 20.V.2016 & 1 & $\mathrm{PPI}_{4}$ \\
\hline & & 26.V.2016 & 2 & $\mathrm{CPE}_{1}, \mathrm{CAA}_{1}$ \\
\hline & & 21.VI.2016 & 2 & $\mathrm{CAA}_{1}, \mathrm{PPI}_{4}$ \\
\hline & & 23.VI.2016 & 1 & $\mathrm{DPI}_{3}$ \\
\hline \multirow[t]{5}{*}{15} & \multirow{5}{*}{$\begin{array}{l}\text { Hemitrichapion (Dimesomyops) } \\
\text { pavidum GERMAR, } 1817\end{array}$} & 19.VI.2014 & 2 & DLP, DPP \\
\hline & & 19.V.2016 & 1 & $\mathrm{LMT}_{2}$ \\
\hline & & 26.V.2016 & 1 & $\mathrm{BMT}_{4}^{2}$ \\
\hline & & 21.VI.2016 & 1 & $\mathrm{BMH}_{4}^{4}$ \\
\hline & & 23.VI.2016 & 1 & $\mathrm{LAA}_{2}{ }_{2}$ \\
\hline \multirow[t]{2}{*}{16} & \multirow{2}{*}{$\begin{array}{l}\text { Holotrichapion } \\
\text { (Holotrichapion) ononis } \\
\text { KIRBY, } 1808\end{array}$} & 20.V.2016 & 1 & $\mathrm{SLMH}_{3}$ \\
\hline & & 26.V.2016 & 2 & $\mathrm{BMB}_{4}, \mathrm{BMT}_{4}$ \\
\hline 17 & $\begin{array}{l}\text { Ischnopterapion } \\
\text { (Ischnopterapion) loti } \\
\text { KIRBY, } 1808\end{array}$ & 19.VI.2014 & 1 & DFPC \\
\hline \multirow[t]{4}{*}{18} & \multirow{4}{*}{$\begin{array}{l}\text { Ischnopterapion (Chlorapion) } \\
\text { virens HERBST, } 1797\end{array}$} & 19.VI.2014 & 2 & DPP \\
\hline & & 19.V.2016 & 1 & $\mathrm{LPI}_{2}$ \\
\hline & & 22.VI.2016 & 1 & $\mathrm{SLMH}_{3}$ \\
\hline & & 23.VI.2016 & 1 & $\mathrm{DPE}_{3}$ \\
\hline \multirow[t]{2}{*}{19} & \multirow{2}{*}{$\begin{array}{l}\text { Oxystoma pomonae } \\
\text { FABRICIUS, } 1798\end{array}$} & 19.V.2016 & 1 & $\mathrm{DPI}_{3}$ \\
\hline & & 26.V.2016 & 1 & $\mathrm{BAA}_{4}$ \\
\hline 20 & $\begin{array}{l}\text { Perapion (Perapion) } \\
\text { curtirostre GERMAR, } 1817\end{array}$ & 26.V.2016 & 3 & $\mathrm{CAA}_{1}, \mathrm{BAA}_{4}$ \\
\hline \multirow[t]{4}{*}{21} & \multirow{4}{*}{$\begin{array}{l}\text { Protapion apricans } \\
\text { HeRBST, } 1787\end{array}$} & 19.VI.2014 & 1 & $\mathrm{DPC}$ \\
\hline & & 20.V.2016 & 3 & $\mathrm{SLMH}_{3}, \mathrm{PPI}_{4}$ \\
\hline & & 26.V.2016 & 6 & $\begin{array}{l}\mathrm{BMT}_{4}, \mathrm{BMH}_{4}, \\
\mathrm{CPE}_{1}, \mathrm{CAA}_{1}\end{array}$ \\
\hline & & 23.VI.2016 & 1 & $\mathrm{LAA}_{2}$ \\
\hline \multirow[t]{3}{*}{22} & \multirow{3}{*}{$\begin{array}{l}\text { Protapion fulvipes } \\
\text { FOURCROY, } 1785\end{array}$} & 19.V.2016 & 1 & $\mathrm{DPI}_{3}$ \\
\hline & & 20.V.2016 & 2 & $\mathrm{SLMB}_{3}, \mathrm{SLMH}_{3}$ \\
\hline & & 26.V.2016 & 1 & $\mathrm{CPE}_{1}$ \\
\hline 23 & $\begin{array}{l}\text { Protapion gracilipes } \\
\text { DIETRICH, } 1857\end{array}$ & 26.V.2016 & 2 & $\mathrm{BAA}_{4}$ \\
\hline
\end{tabular}

\begin{tabular}{|c|c|c|c|c|}
\hline $\begin{array}{l}\text { Nr. } \\
\text { crt. }\end{array}$ & Taxa & Date & $\mathbf{N}$ & $\begin{array}{l}\text { Localities / } \\
\text { biotopes }\end{array}$ \\
\hline 24 & $\begin{array}{l}\text { Protapion interjectum } \\
\text { DeSBROCHERS des LOGES, } 1895\end{array}$ & 20.V.2016 & 1 & $\mathrm{BCMT}_{1}$ \\
\hline \multirow[t]{4}{*}{25} & Protapion ononidis & 26.V.2016 & 11 & $\mathrm{BMT}_{4}, \mathrm{BAA}_{4}$ \\
\hline & GYLLENHAL, 1827 & 21.VI.2016 & 9 & $\begin{array}{l}\mathrm{BMH}_{4}, \mathrm{BMT}_{4}, \\
\mathrm{BMB}_{4}\end{array}$ \\
\hline & & 22.VI.2016 & 3 & $\mathrm{SLMH}_{3}, \mathrm{SLMB}_{3}$ \\
\hline & & 23.VI.2016 & 1 & $\mathrm{LMT}_{2}$ \\
\hline \multirow[t]{6}{*}{26} & Protapion nigritarse & 19.VI.2014 & 3 & DFPC \\
\hline & KIRBY, 1808 & 19.V.2016 & 2 & $\mathrm{LMH}_{2}$ \\
\hline & & 20.V.2016 & 3 & $\begin{array}{l}\mathrm{SLMT}_{3}, \mathrm{SLMB}_{3}, \\
\mathrm{BCMH}_{1}\end{array}$ \\
\hline & & 26.V.2016 & 5 & $\begin{array}{l}\mathrm{BMB}_{4}, \mathrm{BMH}_{4} \\
\mathrm{DSPI}_{4}\end{array}$ \\
\hline & & 21.VI.2016 & 1 & $\mathrm{CAA}_{1}^{4}$ \\
\hline & & 23.VI.2016 & 1 & $\mathrm{LMB}_{2}$ \\
\hline \multirow[t]{5}{*}{27} & Protapion ruficrus & 19.VI.2014 & 14 & DPP, DFPC \\
\hline & GERMAR, 1817 & 11.VIII.2014 & 1 & DFPC \\
\hline & & 20.V.2016 & 5 & $\begin{array}{l}\mathrm{SLMT}_{3}, \mathrm{SLMH}_{3}, \\
\mathrm{BCMH}_{1}\end{array}$ \\
\hline & & 26.V.2016 & 3 & $\mathrm{BMB}_{4}$ \\
\hline & & 21.VI.2016 & 4 & $\mathrm{CAA}_{1}, \mathrm{BAA}_{4}, \mathrm{BMB}_{4}$ \\
\hline \multirow[t]{5}{*}{28} & Protapion trifolii & 20.V.2016 & 2 & $\mathrm{BCMH}_{1}, \mathrm{PPI}_{4}$ \\
\hline & LiNNAEUS, 1768 & 26.V.2016 & 1 & $\mathrm{BMH}_{4}$ \\
\hline & Family Curculionidae & & & \\
\hline & Subfamily Conoderinae & & & \\
\hline & Tribe Baridini & & & \\
\hline \multirow[t]{3}{*}{29} & Malvaevora timida timida & 11.V.2016 & 1 & $\mathrm{FCPE}_{4}$ \\
\hline & Rossi, 1792 & 26.V.2016 & 3 & $\mathrm{FCPE}_{4}^{4}$ \\
\hline & Tribe Ceutorhynchini & & & \\
\hline \multirow[t]{2}{*}{30} & Ceutorhynchus erysimi & 19.V.2016 & 1 & $\mathrm{LMH}_{2}$ \\
\hline & FABRICIUS, 1787 & 20.V.2016 & 1 & $\mathrm{SLMT}_{3}^{2}$ \\
\hline 31 & $\begin{array}{l}\text { Ceutorhynchus parvulus } \mathrm{CH}_{\mathrm{H}} \\
\text { BRISOUT de BARNEVILLE, } 1869\end{array}$ & 19.V.2016 & 1 & $\mathrm{LPI}_{2}$ \\
\hline 32 & $\begin{array}{l}\text { Ceutorhynchus turbatus } \\
\text { SCHULTZE, } 1903\end{array}$ & 19.V.2016 & 1 & $\mathrm{LMH}_{2}$ \\
\hline
\end{tabular}




\begin{tabular}{|c|c|c|c|c|}
\hline $\begin{array}{l}\text { Nr. } \\
\text { crt. }\end{array}$ & Taxa & Date & $\mathbf{N}$ & $\begin{array}{c}\text { Localities / } \\
\text { biotopes }\end{array}$ \\
\hline 33 & $\begin{array}{l}\text { Ceutorhynchus sulcicollis } \\
\text { PAYKUL, } 1800\end{array}$ & 26.V.2016 & 1 & $\mathrm{CPE}_{1}$ \\
\hline 34 & $\begin{array}{l}\text { Ceutorhynchus posthumus } \\
\text { GERMAR, } 1824\end{array}$ & 26.V.2016 & 1 & $\mathrm{CPE}_{1}$ \\
\hline 35 & $\begin{array}{l}\text { Coeliastes lamii } \\
\text { FABRICIUS, } 1792\end{array}$ & 26.V.2016 & 1 & $\mathrm{FCPE}_{4}$ \\
\hline \multirow[t]{4}{*}{36} & \multirow{4}{*}{$\begin{array}{l}\text { Glocianus punctiger } \\
\text { GYLLENHAL, } 1837\end{array}$} & 19.VI.2014 & 1 & DPP \\
\hline & & 20.V.2016 & 1 & $\mathrm{BCMH}_{1}$ \\
\hline & & 26.V.2016 & 1 & $\mathrm{CAA}_{1}$ \\
\hline & & 24.VI.2016 & 1 & $\mathrm{FCPE}_{4}$ \\
\hline \multirow[t]{2}{*}{37} & \multirow{2}{*}{$\begin{array}{l}\text { Mogulones euphorbiae } \mathrm{CH} . \\
\text { BRISOUT de BARNEVILLE, } 1866\end{array}$} & 26.V.2016 & 3 & $\mathrm{BMB}_{4}^{4}, \mathrm{CPE}_{1}$ \\
\hline & & 20.V.2016 & 1 & $\mathrm{PPI}_{4}$ \\
\hline 38 & $\begin{array}{l}\text { *Mogulones larvatus } \\
\text { SCHULTZE, } 1897\end{array}$ & 11.VIII.2014 & 1 & DFPC \\
\hline \multirow[t]{3}{*}{39} & \multirow{3}{*}{$\begin{array}{l}\text { Thamiocolus pubicollis } \\
\text { GYLLENHAL, } 1837\end{array}$} & 19.VI.2014 & 2 & DFPC \\
\hline & & 26.V.2016 & 2 & $\mathrm{BMT}_{4}, \mathrm{BAA}_{4}$ \\
\hline & & 21.VI.2016 & 4 & $\begin{array}{l}\mathrm{BMT}_{4}, \mathrm{BAA}_{4} \\
\mathrm{BMB}_{4}\end{array}$ \\
\hline \multirow[t]{4}{*}{40} & \multirow{4}{*}{$\begin{array}{l}\text { Trichosirocalus troglodytes } \\
\text { FABRICIUS, } 1787\end{array}$} & 19.VI.2014 & 1 & DFPC \\
\hline & & 20.V.2016 & 1 & $\mathrm{PPI}_{4}$ \\
\hline & & 26.V.2016 & 5 & $\mathrm{BMB}_{4}, \mathrm{FCPE}_{4}$ \\
\hline & & 21.VI.2016 & 4 & $\mathrm{DSPI}_{1}, \mathrm{PPI}_{4}$ \\
\hline \multirow[t]{2}{*}{41} & $\begin{array}{l}\text { Rhinoncus pericarpius } \\
\text { LINNAEUs, } 1758\end{array}$ & 26.V.2016 & 2 & $\mathrm{BMB}_{4}, \mathrm{BAA}_{4}$ \\
\hline & Tribe Orobitidini & & & \\
\hline \multirow[t]{3}{*}{42} & $\begin{array}{l}\text { Orobitis cyaneus } \\
\text { LinNAEUS, } 1758\end{array}$ & 26.V.2016 & 4 & $\mathrm{BMB}_{4}, \mathrm{BAA}_{4}$ \\
\hline & Subfamily Curculioninae & & & \\
\hline & Tribe Anthonomini & & & \\
\hline 43 & $\begin{array}{l}\text { Anthonomus (Anthonomus) } \\
\text { pedicularius LINNAEUS, } 1758\end{array}$ & 19.VI.2014 & 3 & DPS \\
\hline 44 & $\begin{array}{l}\text { Anthonomus (Anthonomus) } \\
\text { pomorum LiNNAEUs, } 1758\end{array}$ & 26.V.2016 & 1 & $\mathrm{FCPE}_{4}$ \\
\hline
\end{tabular}

\begin{tabular}{|c|c|c|c|c|}
\hline $\begin{array}{l}\text { Nr. } \\
\text { crt. }\end{array}$ & Taxa & Date & $\mathbf{N}$ & $\begin{array}{l}\text { Localities / } \\
\text { biotopes }\end{array}$ \\
\hline \multirow[t]{5}{*}{45} & \multirow[t]{4}{*}{$\begin{array}{l}\text { Anthonomus (Anthonomus) rubi } \\
\text { Herbst, } 1795\end{array}$} & 20.V.2016 & 4 & $\begin{array}{l}\mathrm{SLMT}_{3}, \mathrm{SLAA}_{3} \\
\mathrm{SLMH}_{3}\end{array}$ \\
\hline & & 21.VI.2016 & 1 & $\mathrm{PPI}_{4}$ \\
\hline & & 22.VI.2016 & 1 & $\mathrm{BCMB}_{1}$ \\
\hline & & 23.VI.2016 & 1 & $\mathrm{LPI}_{2}$ \\
\hline & \multicolumn{4}{|l|}{ Tribe Mecinini } \\
\hline 46 & $\begin{array}{l}\text { Cleopomiarus distinctus } \\
\text { BOHEMAN, } 1845\end{array}$ & 23.VI.2016 & 1 & $\mathrm{LMT}_{2}$ \\
\hline 47 & $\begin{array}{l}\text { Gymnetron veronicae } \\
\text { GERMAR, } 1821\end{array}$ & 26.V.2016 & 1 & $\mathrm{CPE}_{1}$ \\
\hline 48 & Mecinus labilis HeRBST, 1795 & 26.V.2016 & 1 & $\mathrm{PPI}_{4}$ \\
\hline 49 & $\begin{array}{l}\text { Mecinus plantaginis } \\
\text { EPPELSHEIMER, } 1875\end{array}$ & 20.V.2016 & 1 & $\mathrm{SLMB}_{3}$ \\
\hline \multirow[t]{3}{*}{50} & **Mecinus pyraster & 20.V.2016 & 1 & $\mathrm{SLMH}_{3}$ \\
\hline & HERBST, 1795 & 26.V.2016 & 1 & $\mathrm{FCPE}_{4}^{3}$ \\
\hline & & 21.VI.2016 & 2 & $\mathrm{DSPI}_{1}, \mathrm{PPI}_{4}$ \\
\hline \multirow[t]{4}{*}{51} & Miarus ajugae Herbst, 1795 & 20.V.2016 & 1 & $\mathrm{SLAA}_{3}$ \\
\hline & & 26.V.2016 & 3 & $\mathrm{BMB}_{4}$ \\
\hline & Tribe Rhamphini & & & \\
\hline & Subtribe Rhamphina & & & \\
\hline \multirow[t]{2}{*}{52} & $\begin{array}{l}\text { Pseudorchestes pratensis } \\
\text { GERMAR, } 1821\end{array}$ & 26.V.2016 & 1 & $\mathrm{FCPE}_{4}$ \\
\hline & Tribe Smicronychini & & & \\
\hline \multirow[t]{3}{*}{53} & $\begin{array}{l}\text { Smicronyx (Smicronyx) } \\
\text { jungermanniae ReIcH, } 1797\end{array}$ & 19.VI.2014 & 1 & DPP \\
\hline & Tribe Tychiini & & & \\
\hline & Subtribe Tychiina & & & \\
\hline \multirow[t]{3}{*}{54} & Tychius cuprifer PANZER, 1799 & 19.V.2016 & 1 & $\mathrm{LMH}_{2}$ \\
\hline & & 20.V.2016 & 4 & $\begin{array}{l}\mathrm{PPI}_{4}, \mathrm{SLAA}_{3}, \\
\mathrm{BCMH}_{1}\end{array}$ \\
\hline & & 26.V.2016 & 2 & $\mathrm{CPE}_{1} \mathrm{PPI}_{4}$ \\
\hline \multirow[t]{3}{*}{55} & Tychius picirostris & 20.V.2016 & 1 & $\mathrm{SLAA}_{3}$ \\
\hline & FABRICIUS, 1787 & 26.V.2016 & 11 & $\begin{array}{l}\mathrm{BMT}_{4}, \mathrm{FCPE}_{4} \\
\mathrm{CPE}_{1}, \mathrm{CAA}_{1}, \mathrm{PPI}_{4}\end{array}$ \\
\hline & & 21.VI.2016 & 1 & DSPI $_{1}$ \\
\hline
\end{tabular}




\section{Taxa} LinNAEUS, 1758
56 Tychius quinquepunctatus

\begin{tabular}{|lll}
\multicolumn{1}{c}{ Date } & N & \multicolumn{1}{c}{$\begin{array}{c}\text { Localities / } \\
\text { biotopes }\end{array}$} \\
\hline 19.VI.2014 & 4 & DPP, DFPC $^{\text {DI. }}$ \\
\hline 20.V.2016 & 1 & $\mathrm{SLAA}_{3}$ \\
\hline 26.V.2016 & 9 & $\begin{array}{l}\mathrm{BMB}_{4}, \mathrm{BMH}_{4}, \\
\mathrm{BAA}_{4}, \mathrm{CPE}_{1}\end{array}$ \\
\hline 22.VI.2016 & 1 & $\mathrm{SLMT}_{3}$ \\
\hline 23.VI.2016 & 1 & $\mathrm{LPE}_{2}$ \\
\hline
\end{tabular}

Subfamily Entiminae

\section{Tribe Otiorhynchini}

57 Otiorhynchus (Cryphiphorus) ligustici LinNaEus, 1758

\begin{tabular}{l} 
19.V.2016 \\
\hline 20.V.2016 \\
\hline 26.V.2016
\end{tabular}

\section{Tribe Phyllobini}

58 *Argoptochus (Argoptochus) quadrisignatus $\mathrm{BACH}, 1856$

59 Phyllobius (Nemoicus) oblongus Linnaeus, 1758

$60 \quad$ Phyllobius (Phyllobius) betulinus

BeChSTEIN \& SCHARFENBERG, 1805

$$
\text { 19.V.2016 } 11 \mathrm{LMB}_{2}
$$$$
\text { 20.V.2016 } 2 \quad \mathrm{BCMB}_{1}, \mathrm{SLMB}_{3}
$$

19.V.2016 $11 \mathrm{LMB}_{2}$

20.V.2016 6 BCMB $_{1}, \mathrm{BCMT}_{1}$, $\mathrm{BCMH}_{1}, \mathrm{SLMH}_{3}$

\begin{tabular}{llll}
\cline { 3 - 4 } 61 & 26.V.2016 & 5 & $\mathrm{FCPE}_{4}, \mathrm{CAA}_{1}, \mathrm{PPI}_{4}$ \\
\hline
\end{tabular}
pilicornis

Desbrouchers des Loges, 1873

62 Phyllobius (Phyllobius) pyri LinNAEUS, 1758

\begin{tabular}{lll} 
19.V.2016 & 6 & $\begin{array}{l}\mathrm{LPE}_{2}, \mathrm{LMB}_{2}, \mathrm{LMT}_{2}, \\
\mathrm{LAA}_{2}\end{array}$ \\
\hline 20.V.2016 & 1 & $\mathrm{SLMB}_{3}$ \\
\hline 26.V.2016 & 1 & $\mathrm{BAA}_{4}$ \\
\hline $26 . V .2016$ & 2 & $\mathrm{BAA}_{4}, \mathrm{CPE}_{1}$ \\
\hline $21 . \mathrm{VI} .2016$ & 1 & $\mathrm{BMT}_{4}$ \\
\hline
\end{tabular}

63 Phyllobius (Phyllobius) seladonius BRULLÉ, 1832 Tribe Polydrusini

64 Liophloeus (Liophloeus) tessulatus O. F. MüLLER, 1776

65 Polydrusus (Chrysoyphis) thalassinus GyLLENHAL, 1834

\section{V.2016 1 CAA}

19.VI.2014 1 DPD

\begin{tabular}{|c|c|c|c|c|}
\hline $\begin{array}{l}\text { Nr. } \\
\text { crt. }\end{array}$ & Taxa & Date & $\mathbf{N}$ & $\begin{array}{l}\text { Localities / } \\
\text { biotopes }\end{array}$ \\
\hline \multirow[t]{2}{*}{66} & \multirow[t]{2}{*}{$\begin{array}{l}\text { Polydrusus (Eurodrusus) } \\
\text { confluens STEPHENS, } 1831\end{array}$} & 20.V.2016 & 27 & $\begin{array}{l}\mathrm{BCMB}_{1}, \mathrm{SLMB}_{3}, \\
\mathrm{BCMT}_{1}, \mathrm{SLMH}_{3}, \\
\mathrm{SLMT}_{3}\end{array}$ \\
\hline & & 26.V.2016 & 3 & $\mathrm{BMB}_{4}, \mathrm{BAA}_{4}, \mathrm{PPI}_{4}$ \\
\hline 67 & $\begin{array}{l}\text { Polydrusus (Eurodrusus) } \\
\text { pilosus GREDLER, } 1866\end{array}$ & 20.V.2016 & 1 & $\mathrm{SLMB}_{3}$ \\
\hline 68 & $\begin{array}{l}\text { Polydrusus (Eustolus) flavipes } \\
\text { DE GEER, } 1775\end{array}$ & 26.V.2016 & 1 & $\mathrm{BAA}_{4}$ \\
\hline 69 & $\begin{array}{l}\text { Polydrusus (Eustolus) } \\
\text { impressifrons GYLLENHAL, } 1834\end{array}$ & 19.V.2016 & 1 & $\mathrm{DPI}_{3}$ \\
\hline 70 & $\begin{array}{l}\text { Polydrusus (Eustolus) } \\
\text { pterygomalis BoHEMAN, } 1840\end{array}$ & 19.V.2016 & 1 & $\mathrm{DPI}_{3}$ \\
\hline \multirow[t]{2}{*}{71} & $\begin{array}{l}\text { Polydrusus (Poecilodrusus) } \\
\text { viridicinctus GyLlenhal, } 1834\end{array}$ & 19.VI.2014 & 1 & DPS \\
\hline & Tribe Psallidiini & & & \\
\hline \multirow[t]{2}{*}{72} & $\begin{array}{l}\text { Mesagroicus obscurus } \\
\text { BOHEMAN, } 1840\end{array}$ & 19.V.2016 & 1 & $\mathrm{LMB}_{2}$ \\
\hline & Tribe Sciaphilini & & & \\
\hline 73 & $\begin{array}{l}\text { Brachysomus villosulus } \\
\text { GERMAR, } 1824\end{array}$ & 20.V.2016 & 2 & $\mathrm{BCMH}_{1}$ \\
\hline \multirow[t]{5}{*}{74} & $\begin{array}{l}\text { Foucartia ptochoides } \\
\text { BACH, } 1856\end{array}$ & 19.V.2016 & 87 & $\begin{array}{l}\mathrm{LAA}_{2}, \mathrm{LPE}_{2}, \mathrm{LPI}_{2} \\
\mathrm{LMH}_{2}, \mathrm{LMB}_{2} \\
\mathrm{LMT}_{2}\end{array}$ \\
\hline & & 20.V.2016 & 26 & $\begin{array}{l}\text { BCMB1, } \mathrm{SLMB}_{3}, \\
\text { BCMH }_{1}, \mathrm{SLMH}_{3}\end{array}$ \\
\hline & & 26.V.2016 & 11 & $\mathrm{CAA}_{1}$ \\
\hline & & 22.VI.2016 & 4 & $\begin{array}{l}\mathrm{SLMH}_{3}, \mathrm{SLMB}_{3}, \\
\mathrm{SLAA}_{3}\end{array}$ \\
\hline & & 23.VI.2016 & 4 & $\mathrm{LPI}_{2}, \mathrm{LMB}_{2}$ \\
\hline \multirow[t]{2}{*}{75} & Parafoucartia squamulata & 19.V.2016 & 1 & $\mathrm{LMB}_{2}$ \\
\hline & HERBST, 1795 & 20.V.2016 & 1 & $\mathrm{SLAA}_{3}$ \\
\hline
\end{tabular}




\begin{tabular}{|c|c|c|c|c|}
\hline $\begin{array}{l}\text { Nr. } \\
\text { crt. }\end{array}$ & Taxa & Date & $\mathbf{N}$ & $\begin{array}{c}\text { Localities / } \\
\text { biotopes }\end{array}$ \\
\hline \multirow[t]{6}{*}{76} & \multirow{6}{*}{$\begin{array}{l}\text { Paophilus afflatus } \\
\text { BoHEMAN, } 1883\end{array}$} & 19.VI.2014 & 1 & DPP \\
\hline & & 19.V.2016 & 29 & $\begin{array}{l}\mathrm{LPE}_{2}, \mathrm{LPI}_{2}, \mathrm{LMB}_{2}, \\
\mathrm{LMT}_{2}\end{array}$ \\
\hline & & 20.V.2015 & 7 & $\begin{array}{l}\mathrm{BCMB}_{1}, \mathrm{BCMT}_{1}, \\
\mathrm{SLMT}_{3}\end{array}$ \\
\hline & & 26.V.2016 & 4 & $\mathrm{PPI}_{4}$ \\
\hline & & 21.VI.2016 & 3 & $\mathrm{DSPI}_{1}, \mathrm{CAA}_{1}$ \\
\hline & & 23.VI.2016 & 6 & $\mathrm{LPE}_{2}, \mathrm{LMB}_{2}$ \\
\hline \multirow[t]{8}{*}{77} & \multirow[t]{8}{*}{$\begin{array}{l}\text { Sciaphobus (Sciaphobus) } \\
\text { caesius HAMPE, } 1870\end{array}$} & 19.VI.2014 & 42 & $\begin{array}{l}\text { DPS, DPC, DLP, } \\
\text { DPP }\end{array}$ \\
\hline & & 11.VIII.2014 & 1 & DPP \\
\hline & & 19.V.2016 & 32 & $\begin{array}{l}\mathrm{LPE}_{2}, \mathrm{LPI}_{2}, \mathrm{LMH}_{2}, \\
\mathrm{LMT}_{2}, \mathrm{LMB}_{2}\end{array}$ \\
\hline & & 20.V.2016 & 25 & $\begin{array}{l}\mathrm{SLAA}_{3}, \mathrm{SLMT}_{3} \\
\mathrm{SLMB}_{3}, \mathrm{BCMB}_{1}, \\
\mathrm{BCMH}_{1}, \mathrm{SLMH}_{3}, \\
\mathrm{BCMT}_{1}, \mathrm{BMT}_{4}\end{array}$ \\
\hline & & 26.V.2016 & 31 & $\begin{array}{l}\mathrm{BMB}_{4}, \mathrm{BAA}_{4}, \\
\mathrm{CPE}_{1}, \mathrm{CAA}_{1}, \mathrm{PPI}_{4}\end{array}$ \\
\hline & & 21.VI.2016 & 28 & $\begin{array}{l}\mathrm{BMB}_{4}, \mathrm{BMT}_{4}, \\
\mathrm{BAA}_{4}, \mathrm{DSPI}_{4}\end{array}$ \\
\hline & & 22.VI.2016 & 14 & $\begin{array}{l}\mathrm{SLMH}_{3}, \mathrm{SLMB}_{3}, \\
\mathrm{SLAA}_{3}, \mathrm{BCMB}_{1}\end{array}$ \\
\hline & & 23.VI.2016 & 69 & $\begin{array}{l}\mathrm{LMB}_{2}, \mathrm{LAA}_{2}, \\
\mathrm{LMT}_{2}, \mathrm{LPI}_{2}, \mathrm{LPE}_{2}, \\
\mathrm{LPE}_{3}, \mathrm{DPI}_{3}\end{array}$ \\
\hline
\end{tabular}

\begin{tabular}{|c|c|c|c|c|}
\hline $\begin{array}{l}\text { Nr. } \\
\text { crt. }\end{array}$ & Taxa & Date & $\mathbf{N}$ & $\begin{array}{c}\text { Localities / } \\
\text { biotopes }\end{array}$ \\
\hline \multirow[t]{8}{*}{78} & \multirow[t]{7}{*}{ Eusomus ovulum Germar, 1824} & 19.VI.2014 & 2 & DPC, DLP \\
\hline & & 19.V.2016 & 41 & $\begin{array}{l}\mathrm{DPI}_{3}, \mathrm{LPE}_{2}, \mathrm{LPI}_{2}, \\
\mathrm{LMH}_{2}, \mathrm{LAA}_{2}, \\
\mathrm{LMT}_{2}, \mathrm{LMB}_{2}\end{array}$ \\
\hline & & 20.V.2016 & 53 & $\begin{array}{l}\mathrm{BCMH}_{1}, \mathrm{BCMT}_{1}, \\
\mathrm{SLMH}_{3}, \mathrm{BCMB}_{1}, \\
\mathrm{SLMB}_{3}, \mathrm{SLMT}_{3}, \\
\mathrm{SLA}_{2}, \mathrm{PPI}_{4}\end{array}$ \\
\hline & & 26.V.2016 & 21 & $\begin{array}{l}\mathrm{BMB}_{4}, \mathrm{BMT}_{4}, \\
\mathrm{BAA}_{4}, \mathrm{FCPE}_{4}, \\
\mathrm{CPE}_{1}, \mathrm{CAA}_{1}, \mathrm{PPI}_{4}\end{array}$ \\
\hline & & 21.VI.2016 & 15 & $\begin{array}{l}\mathrm{BMB}_{4}, \mathrm{BMT}_{4}, \\
\mathrm{FCPE}_{4}, \mathrm{DSPI}_{1}, \mathrm{PPI}_{4}\end{array}$ \\
\hline & & 22.VI.2016 & 10 & $\begin{array}{l}\mathrm{BCMT}_{1}, \mathrm{BCMB}_{1} \\
\mathrm{BCMH}_{1}, \mathrm{SLMT}_{3}\end{array}$ \\
\hline & & 23.VI.2016 & 16 & $\begin{array}{l}\mathrm{LMB}_{2}, \mathrm{LAA}_{2}, \\
\mathrm{LMT}_{2}, \mathrm{LMH}_{2}, \mathrm{LPI}_{2}, \\
\mathrm{LPE}_{2}, \mathrm{DPI}_{3}\end{array}$ \\
\hline & \multicolumn{4}{|l|}{ Tribe Sitonini } \\
\hline \multirow[t]{4}{*}{79} & \multirow{4}{*}{$\begin{array}{l}\text { Sitona (Sitona) hispidulus } \\
\text { FABRICIUS, } 1776\end{array}$} & 19.VI.2014 & 1 & DPS \\
\hline & & 20.V.2016 & 1 & $\mathrm{SLAA}_{3}$ \\
\hline & & 21.VI.2016 & 2 & $\mathrm{PPI}_{4}$ \\
\hline & & 23.VI.2016 & 1 & $\mathrm{LPE}_{2}$ \\
\hline \multirow[t]{3}{*}{80} & \multirow{3}{*}{$\begin{array}{l}\text { Sitona (Sitona) humeralis } \\
\text { STEPHENS, } 1831\end{array}$} & 26.V.2016 & 2 & $\mathrm{PPI}_{4}$ \\
\hline & & 21.VI.2016 & 1 & $\mathrm{FCPE}_{4}$ \\
\hline & & 23.VI.2016 & 1 & $\mathrm{LMB}_{2}$ \\
\hline \multirow[t]{3}{*}{81} & \multirow{3}{*}{$\begin{array}{l}\text { Sitona (Sitona) inops } \\
\text { Gyllenhal, } 1832\end{array}$} & 19.V.2016 & 3 & $\mathrm{LMH}_{2}, \mathrm{LMT}_{2}$ \\
\hline & & 20.V.2016 & 5 & $\mathrm{SLMT}_{3}, \mathrm{SLMH}_{3}$ \\
\hline & & 23.VI.2016 & 1 & $\mathrm{LPE}_{2}$ \\
\hline \multirow[t]{2}{*}{82} & \multirow{2}{*}{$\begin{array}{l}\text { Sitona (Sitona) languidus } \\
\text { (GYLLENHAL, 1834) }\end{array}$} & 19.VI.2014 & 1 & DPS \\
\hline & & 19.V.2016 & 1 & $\mathrm{LAA}_{2}$ \\
\hline \multirow[t]{3}{*}{83} & \multirow{3}{*}{$\begin{array}{l}\text { Sitona (Sitona) lateralis } \\
\text { GYLLENHAL } 1834 \text { (= ononidis } \\
\text { SHARP, 1860) }\end{array}$} & 19.V.2016 & 3 & $\mathrm{LPI}_{2}$ \\
\hline & & 26.V.2016 & 20 & $\begin{array}{l}\mathrm{BMB}_{4}, \mathrm{BMT}_{4}, \\
\mathrm{CAA}_{1}\end{array}$ \\
\hline & & 21.VI.2016 & 6 & $\mathrm{BMT}_{4}$ \\
\hline
\end{tabular}




\begin{tabular}{|c|c|c|c|c|}
\hline $\begin{array}{l}\text { Nr. } \\
\text { crt. }\end{array}$ & Taxa & Date & $\mathbf{N}$ & $\begin{array}{l}\text { Localities / } \\
\text { biotopes }\end{array}$ \\
\hline 84 & $\begin{array}{l}\text { Sitona (Sitona) obsoletus } \\
\text { obsoletus GMELIN, } 1790 \text { (= } \\
\text { lepidus GYLLENHAL } 1834 \text { ) }\end{array}$ & 21.VI.2016 & 1 & $\mathrm{PPI}_{4}$ \\
\hline 85 & $\begin{array}{l}\text { Sitona (Sitona) puncticollis } \\
\text { Stephens, } 1831\end{array}$ & 21.VI.2016 & 1 & $\mathrm{PPI}_{4}$ \\
\hline \multirow[t]{4}{*}{86} & \multirow{4}{*}{$\begin{array}{l}\text { Sitona (Sitona) striatellus } \\
\text { GyLlENHAL, } 1834\end{array}$} & 19.V.2016 & 1 & $\mathrm{LAA}_{2}$ \\
\hline & & 20.V.2016 & 1 & $\mathrm{SLMB}_{3}^{2}$, \\
\hline & & 26.V.2016 & 2 & $\begin{array}{l}\mathrm{BMB}_{4}, \mathrm{BAA}_{4}, \\
\mathrm{CAA}_{1}\end{array}$ \\
\hline & & 21.VI.2016 & 3 & $\begin{array}{l}\mathrm{BMT}_{4}, \mathrm{BMB}_{4} \\
\mathrm{BMH}_{4}\end{array}$ \\
\hline \multirow[t]{3}{*}{87} & \multirow{3}{*}{$\begin{array}{l}\text { Sitona (Sitona) sulcifrons } \\
\text { THUNBERG, } 1789\end{array}$} & 19.VI.2014 & 1 & DPS \\
\hline & & 11.VIII.2014 & 1 & DFPC \\
\hline & & 26.V.2016 & 5 & $\mathrm{BMB}_{4}, \mathrm{BAA}_{4}$ \\
\hline 88 & $\begin{array}{l}\text { Sitona (Sitona) tenuis } \\
\text { RoSENHAUER, } 1847\end{array}$ & 11.VIII.2014 & 1 & DFPC \\
\hline \multirow[t]{6}{*}{89} & \multirow{5}{*}{$\begin{array}{l}\text { Sitona (Sitona) waterhousei } \\
\text { WALton, } 1846\end{array}$} & 19.VI.2014 & 1 & DPS \\
\hline & & 19.V.2016 & 1 & $\mathrm{LPI}_{2}$ \\
\hline & & 20.V.2016 & 1 & $\mathrm{BCMB}_{1}$ \\
\hline & & 26.V.2016 & 8 & $\begin{array}{l}\mathrm{BMB}_{4}, \mathrm{BAA}_{4} \\
\mathrm{BMH}_{4}, \mathrm{PPI}_{4}\end{array}$ \\
\hline & & 23.VI.2016 & 1 & $\mathrm{LPE}_{2}$ \\
\hline & Tribe Tanymecini & & & \\
\hline \multirow[t]{4}{*}{90} & \multirow{2}{*}{$\begin{array}{l}\text { Tanymecus (Tanymecus) } \\
\text { palliatus FABRICIUS, } 1787\end{array}$} & 21.VI.2016 & 1 & $\mathrm{BAA}_{4}$ \\
\hline & & 23.VI.2016 & 1 & $19 \mathrm{DPI}_{3}$ \\
\hline & \multicolumn{4}{|l|}{ Subfamily Hyperinae } \\
\hline & \multicolumn{4}{|l|}{ Triby Hyperini } \\
\hline \multirow[t]{3}{*}{91} & \multirow{3}{*}{$\begin{array}{l}\text { Donus intermedius } \\
\text { (BoHEMAN, 1842) }\end{array}$} & 19.VI.2014 & 1 & DPS \\
\hline & & 11.VIII.2014 & 1 & DPS \\
\hline & & 21.VI.2016 & 1 & $\mathrm{BMT}_{4}$ \\
\hline 92 & $\begin{array}{l}\text { Hypera (Boreohypera) } \\
\text { diversipunctata SCHRANK, } 1798\end{array}$ & 26.V.2016 & 1 & $\mathrm{BMB}_{4}$ \\
\hline 93 & $\begin{array}{l}\text { Hypera (Dapalinus) } \\
\text { contaminata HerBST, } 1795\end{array}$ & 26.V.2016 & 1 & $\mathrm{CAA}_{1}$ \\
\hline
\end{tabular}

\begin{tabular}{|c|c|c|c|c|}
\hline $\begin{array}{l}\text { Nr. } \\
\text { crt. }\end{array}$ & Taxa & Date & $\mathbf{N}$ & $\begin{array}{l}\text { Localities / } \\
\text { biotopes }\end{array}$ \\
\hline \multirow[t]{4}{*}{94} & \multirow{4}{*}{$\begin{array}{l}\text { Hypera (Dapalinus) meles } \\
\text { FABRICIUS, } 1792\end{array}$} & 19.V.2016 & 5 & $\mathrm{DPE}_{3}, \mathrm{DPI}_{3}, \mathrm{LMT}_{2}$ \\
\hline & & 20.V.2016 & 1 & $\mathrm{PPI}_{4}^{3}$ \\
\hline & & 26.V.2016 & 1 & $\mathrm{BMT}_{4}^{4}, \mathrm{BMB}_{4}$ \\
\hline & & 21.VI.2016 & 1 & $\mathrm{BMT}_{4}$ \\
\hline \multirow[t]{3}{*}{95} & $\begin{array}{l}\text { Hypera (Hypera) miles } \\
\text { PAYKULL, } 1792\end{array}$ & 26.V.2016 & 1 & $\mathrm{CAA}_{1}$ \\
\hline & Subfamily Lixinae & & & \\
\hline & Tribe Lixini & & & \\
\hline \multirow[t]{6}{*}{96} & \multirow[t]{6}{*}{$\begin{array}{l}\text { Larinus (Larinomesius) obtusus } \\
\text { GyLlENHAL, } 1836\end{array}$} & 19.VI.2014 & 46 & $\begin{array}{l}\text { DPS, DPC, DLP, } \\
\text { DFPC, DFD, DPD }\end{array}$ \\
\hline & & 11.VIII.2014 & 7 & DFPC \\
\hline & & 26.V.2016 & 34 & $\begin{array}{l}\mathrm{BMB}_{4}, \mathrm{BMT}_{4}, \\
\mathrm{BAA}_{4}, \mathrm{BMH}_{4}, \\
\mathrm{CAA}_{1}\end{array}$ \\
\hline & & 21.VI.2016 & 93 & $\begin{array}{l}\mathrm{BMB}_{4}, \mathrm{BMT}_{4}, \\
\mathrm{BAA}_{4}, \mathrm{BMH}_{4}, \\
\mathrm{CAA}_{1}, \mathrm{FCPE}_{4}, \mathrm{PPI}_{4}\end{array}$ \\
\hline & & 22.VI.2016 & 22 & $\begin{array}{l}\text { SLMT }_{3}, \text { SLMB }_{3} \\
\text { SLMH }_{3}, \text { BCMT }_{1} \\
\text { BCMH }_{1}\end{array}$ \\
\hline & & 23.VI.2016 & 24 & $\begin{array}{l}\mathrm{LMT}_{2}, \mathrm{LMB}_{2}, \\
\mathrm{LMH}_{2}, \mathrm{LAA}_{2}, \mathrm{LPE}_{2}, \\
\mathrm{LPI}_{2},\end{array}$ \\
\hline \multirow[t]{2}{*}{97} & \multirow{2}{*}{$\begin{array}{l}\text { Larinus (Phyllonomeus) sturnus } \\
\text { SCHALLER, } 1783\end{array}$} & 11.VIII.2014 & 1 & DFPC \\
\hline & & 23.VI.2016 & 1 & $\mathrm{LMH}_{2}$ \\
\hline \multirow[t]{3}{*}{98} & \multirow{3}{*}{$\begin{array}{l}\text { Larinus (Phyllonomeus) } \\
\text { turbinatus GyLlENHAL, } 1836\end{array}$} & 11.VIII.2014 & 2 & DFPC \\
\hline & & 21.VI.2016 & 1 & $\mathrm{BMH}_{4}$, \\
\hline & & 23.VI.2016 & 1 & $\mathrm{LMT}_{2}$ \\
\hline 99 & $\begin{array}{l}\text { *Lixus (Callistolixus) cylindrus } \\
\text { FABRICIUS, } 1781\end{array}$ & 5.VI.2015 & 1 & $\mathrm{SLMT}_{3}^{2}$ \\
\hline 100 & $\begin{array}{l}\text { *Lixus (Ortholixus) angustus } \\
\text { HerbST, } 1795\end{array}$ & 22.VI.2016 & 1 & $\mathrm{SLAA}_{3}$ \\
\hline
\end{tabular}




\begin{tabular}{lllll}
\hline $\begin{array}{c}\text { Nr. } \\
\text { crt. }\end{array}$ & \multicolumn{1}{c}{ Taxa } & Date & N & \multicolumn{1}{c}{$\begin{array}{c}\text { Localities / } \\
\text { biotopes }\end{array}$} \\
\hline & Subfamily Mesoptiliinae & & & \\
\hline & Tribe Magdalidini & 19.V.2016 & 1 & LMT $_{2}$ \\
\hline 101 & $\begin{array}{l}\text { Magdalis (Edo) ruficornis } \\
\text { LINNAEUS, 1758 }\end{array}$ & & & \\
\hline
\end{tabular}

\begin{tabular}{|c|c|c|c|c|}
\hline $\begin{array}{l}\text { Nr. } \\
\text { crt. }\end{array}$ & Taxa & Date & $\mathbf{N}$ & $\begin{array}{c}\text { Localities / } \\
\text { biotopes }\end{array}$ \\
\hline & Subfamily Molytinae & & & \\
\hline & Tribe Lepyrini & & & \\
\hline \multirow[t]{4}{*}{102} & Lepyrus capucinus & 20.V.2015 & 1 & $\mathrm{FCPE}_{4}$ \\
\hline & (SCHALLER, 1783) & 19.V.2016 & 2 & $\mathrm{LAA}_{2}, \mathrm{LMT}_{2}$ \\
\hline & & 20.V.2016 & 2 & $\mathrm{SLMB}_{3}$ \\
\hline & & 26.V.2016 & 1 & $\mathrm{BMT}_{4}$, \\
\hline
\end{tabular}

